\title{
Trends, cycles, interannual variability for three pelagic species west of the Antarctic Peninsula 1993-2008
}

\author{
Robin M. Ross ${ }^{1, *}$, Langdon B. Quetin ${ }^{1}$, Timothy Newberger ${ }^{2}$, C. Tracy Shaw ${ }^{3}$, \\ Janice L. Jones ${ }^{1}$, Stephanie A. Oakes ${ }^{4}$, Kelly J. Moore ${ }^{5}$ \\ ${ }^{1}$ Marine Science Institute, University of California at Santa Barbara, Santa Barbara, CA 93106-6150, USA \\ ${ }^{2}$ NOAA/GMD-1, 325 Broadway, Boulder, CO 80305, USA \\ ${ }^{3}$ Hatfield Marine Science Center, 2030 SE Marine Science Dr, Newport, OR 97365, USA \\ ${ }^{4}$ Marine Ecosystem Division, Office of Science and Technology, NOAA NMFS, 1315 East-West Highway, Silver Springs, \\ MD 20910, USA \\ ${ }^{5}$ Channel Islands National Park, 1901 Spinnaker Drive, Ventura, CA 93001, USA
}

\begin{abstract}
The Palmer Long Term Ecological Research study region west of the Antarctic Peninsula is experiencing warming and changing seasonal sea ice dynamics. Abundance patterns of 3 species of pelagic secondary producers were analyzed for trends, cycles, range extensions or shifts in the location of highest density, and for changes in population dynamics over a $16 \mathrm{yr}$ period (1993-2008). Species analyzed represented different hydrographic regimes and are known to have contrasting responses to seasonal sea ice dynamics: krill Euphausia superba, seasonal sea ice zone; tunicates Salpa thompsoni, warmer waters with minimal sea ice; and larval Antarctic silverfish Pleuragramma antarcticum, cold continental shelf waters. Cycles were observed in grid-wide abundance and recruitment for E. superba. Maximum grid-wide densities did not decrease, but the location of highest densities shifted southward $200 \mathrm{~km}$, away from Adélie penguin rookeries at the northern end. A distinct change post-1999 was apparent in the frequency of occurrence and abundance of $S$. thompsoni. Mixtures of krill and salps became common, but neither peak densities nor the frequency of peak years for salps increased. As with Antarctic krill, highest salp densities shifted southward alongshore. Larval $P$. antarcticum were abundant in the northern coastal region in the early 1990s, but virtually disappeared in that region after 1999/2000. Possible mechanisms underlying these observations include the southerly movement of the sea ice edge during spring, changes in proximity of source populations (salps), and changes in transport pathways (larval P. antarcticum). Patterns are compared to those in the SW Atlantic.
\end{abstract}

KEY WORDS: Time-series for Antarctic zooplankton · Antarctic krill · Antarctic silverfish Resale or republication not permitted without written consent of the publisher

\section{INTRODUCTION}

The response of zooplankton to climate change impacts ecosystem dynamics in multiple ways. Shifts in centers of abundance, range boundaries, community composition, and timing of seasonal activity impact the roles of zooplankton as both prey and grazer. Changes in seasonal activities of animals in marine ecosystems include shifts in seasonal peak biomass or timing of migrations (Walther et al. 2002, Edwards \& Richardson 2004, Mackas et al. 2007, 2012a), and may lead to a mismatch in prey availability for predators or harm species keyed to climate-invariant parameters such as insolation (Edwards \& Richardson 2004, Moline et al. 2008, Mackas et al. 2012b).

The Palmer Long Term Ecological Research (PAL LTER) program is focused on the marine pelagic ecosystem west of the Antarctic Peninsula (wAP) in the 
Southern Ocean. In the wAP, the southern boundary of the Antarctic Circumpolar Current (ACC) parallels the shelf break (Orsi et al. 1995), Upper Circumpolar Deep Water (UCDW) supplies heat to shelf waters (Martinson et al. 2008, Dinniman et al. 2011, Martinson \& McKee 2012), and the Antarctic Peninsula Coastal Current (APCC) flows to the southwest along the continent under ice-free conditions (Moffat et al. 2008). The study region is influenced by the seasonal advance and retreat of sea ice each year. Ecosystem structure and function appear sensitive to variability in seasonal sea ice dynamics (Massom \& Stammerjohn 2010).

The PAL LTER program initiated a taxonomicallyresolved macro-zooplankton and micronekton $(>2 \mathrm{~mm}$ in length) time series in the austral summer of 1993. In this analysis, we focused on 3 species, integral to food web structure, that inhabit zones with different sea ice influences (Mackintosh 1934, Hempel 1987, Siegel \& Piatkowski 1990): 'cold' water in the seasonal sea ice zone (the euphausiid Antarctic krill Euphausia superba); oceanic, 'warm' water with little sea ice (the pelagic tunicate Salpa thompsoni); and coastal, cold continental shelf water associated with permanent pack ice (larval Antarctic silverfish Pleuragramma antarcticum). Antarctic krill (subsequently krill) and $S$. thompsoni often dominate (>50\%) total zooplankton biomass in the PAL LTER study region (Ducklow et al. 2007), either singly or in combination.

Krill is a key species (Smetacek \& Nicol 2005) linking multiple levels of the food web, being a grazer of phytoplankton (Ross et al. 1998, Garibotti et al. 2003, Bernard et al. 2012) and prey for many apex predators (Everson 2000). Krill is long-lived ( 5 to $7 \mathrm{yr}$, Nicol 2000), and swims as well as a small fish (Hamner \& Hamner 2000). Recruitment success has been linked to both seasonal sea ice dynamics and the El NiñoSouthern Oscillation (ENSO) cycle (Siegel \& Loeb 1995, Quetin \& Ross 2003, Loeb et al. 2009, 2010).

In contrast, $S$. thompsoni has a seasonal life cycle, alternating sexual and asexual stages. Small solitaries winter deep in the water column (250 to 1500 m) with UCDW (Foxton 1966, Lancraft et al. 1991), migrate to the surface in late winter/early spring, and bud off aggregate chains. Each solitary may produce up to 800 aggregate zooids, in several chains (Foxton 1966, Daponte et al. 2001). Aggregates release small $(\sim 20 \mathrm{~mm})$ solitaries (Daponte et al. 2001, P. Kremer pers. comm.) $\sim 52$ d from release (Loeb \& Santora 2012). Significant within- and between-year variability in abundance (Foxton 1966) has been linked to seasonal sea ice dynamics and the ENSO cycle (Loeb et al. 1997, 2009, Ross et al. 2008).
Rapid growth rates of zooids and production of aggregate chains mean that populations of salps can increase quickly during spring and summer.

The Antarctic silverfish is a long-lived (21 to $35 \mathrm{yr}$ ) planktivorous pelagic fish that depends on sea ice for spawning and as an early nursery (Vacchi et al. 2004, 2012, La Mesa \& Eastman 2012), and thus may be especially sensitive to decreasing sea ice. In the late $1970 \mathrm{~s}$, schools of subadult (3 to $4 \mathrm{yr}$ old) $P$. antarcticum were observed under the ice pack near Palmer Station (Daniels \& Lipps 1982), and subadult Antarctic silverfish were common in the diet of the Adélie penguins there. The diet of these Adélie penguins has changed (Emslie \& Patterson 2007, Chapman et al. 2011), with few silverfish in the diet in recent times. In this study, larval $P$. antarcticum is an indicator for the 3 to $4 \mathrm{yr}$ old fish that are important prey for several seabirds (La Mesa et al. 2004, La Mesa \& Eastman 2012).

S. thompsoni populations appear to have shifted poleward over the past 2 decades, south of $65^{\circ} \mathrm{S}$ (Chiba et al. 1999, Pakhomov et al. 2002, Atkinson et al. 2004, Ross et al. 2008). Further poleward expansion is predicted with continued warming (Loeb et al. 1997, Atkinson et al. 2004, Moline et al. 2008). Salps may be limited physiologically (Pakhomov et al. $2011 \mathrm{a}, \mathrm{b})$ and unable to reproduce in cold waters (Chiba et al. 1999, Pakhomov et al. 2002, Pakhomov 2004), dictating their 'warm' oceanic distribution. In regions with cold surface waters, Circumpolar Deep Water (CDW) may be a reproductive refuge, e.g. warm water where the life cycle can continue (Pakhomov et al. 2011a,b). Thus, southerly locations where CDW is close to the shelf may be favorable for southward salp expansion onto the shelf. Salp and krill habitats are usually distinct (Atkinson et al. 2004, Loeb et al. 1997, Nicol et al. 2000), but large-scale overlap has occurred in the PAL LTER region (Ross et al. 2008).

The relevant factors for possible impacts of climate change for pelagic polar zooplankters include surface water temperatures, seasonal sea ice dynamics, and circulation's impact on heat input and transport pathways. The wAP is one of the world's most rapidly warming regions, with temperatures increasing on land (King et al. 2003, Turner et al. 2005) and in the ocean (Gille 2002, Meredith \& King 2005, Martinson et al. 2008). Since the late 1970s, sea ice cover has increased in the Antarctic as a whole, but significantly decreased in the Bellingshausen/Amundsen Sea region (Parkinson \& Cavalieri 2012). Seasonality patterns also have changed (Stammerjohn et al. 2008). Additionally, the mean position of the ACC is projected to shift southward, closer to the shelf 
break, as climate changes and westerlies intensify (Böning et al. 2008).

In this study, we analyzed a 16 yr time series (1993 through 2008) for trends and cycles in abundance and distribution of 3 species of macrozooplankton/micronekton in the PAL LTER region during a warming climate. The data spanned 3 krill recruitment cycles (Quetin \& Ross 2003). We explored (1) whether the species act in synchrony or independently, (2) whether there was a poleward shift in either range or highest abundance as predicted for Southern Ocean zooplankton (Pakhomov et al. 2002, Mackey et al. 2012), (3) whether changes in krill were correlated with recruitment dynamics, and (4) whether patterns in this region were similar to those in the SW Atlantic sector of the Southern Ocean.

\section{MATERIALS AND METHODS}

\section{Study region}

The original PAL LTER sampling grid consisted of on/offshore grid lines from just south of Marguerite Bay $\left(000 .^{*}\right)$ to the southern Bransfield Strait $\left(900 .{ }^{*}\right)$ spaced at $100 \mathrm{~km}$ intervals. Standard grid stations on the lines were $20 \mathrm{~km}$ apart from the continent $\left({ }^{*} .000\right)$ to $200 \mathrm{~km}$ offshore $\left({ }^{*} .200\right)$, past the shelf break and into waters $\sim 3000 \mathrm{~m}$ deep (Waters \& Smith 1992). Additional stations were occupied at other locations on some cruises. Station codes consist of 6 digits (e.g. 300.120), 3 for the grid line followed by 3 for the grid station, both in $\mathrm{km}$. For early January to mid-February cruises from 1993 through 2008, the PAL LTER sampling region encompassed the area from just south of Anvers Island (600 line) to just south of Adelaide Island at the mouth of Marguerite Bay (200 line) (Fig. 1). Stations are identified as coastal $(<300 \mathrm{~m}$ deep and Marguerite Bay), shelf ( $300 \mathrm{~m}$ to $750 \mathrm{~m}$ ), or slope $(>750 \mathrm{~m})$ according to bathymetry and hydrographic water column characteristics (Martinson et al. 2008) (Fig. 1). 'Inside north' coastal stations were between the Biscoe Islands (Renaud and Lavoisier Is.) and the mainland (inner 600, 500, and 400 lines), and in Crystal Sound north of Adelaide Island. From 1996, several offshore stations seaward of * 200 were added $(600.220,500.220,500.240$ in most years and 200.220 and 200.260 in the last $3 \mathrm{yr}$ ) to verify the decrease in densities of Antarctic krill and rapid increase in densities of Salpa thompsoni off the shelf. Three stations inside Marguerite Bay, added in 1997, continued east of 200.000 along the 200 transect line as negative stations. Sampling was conducted from

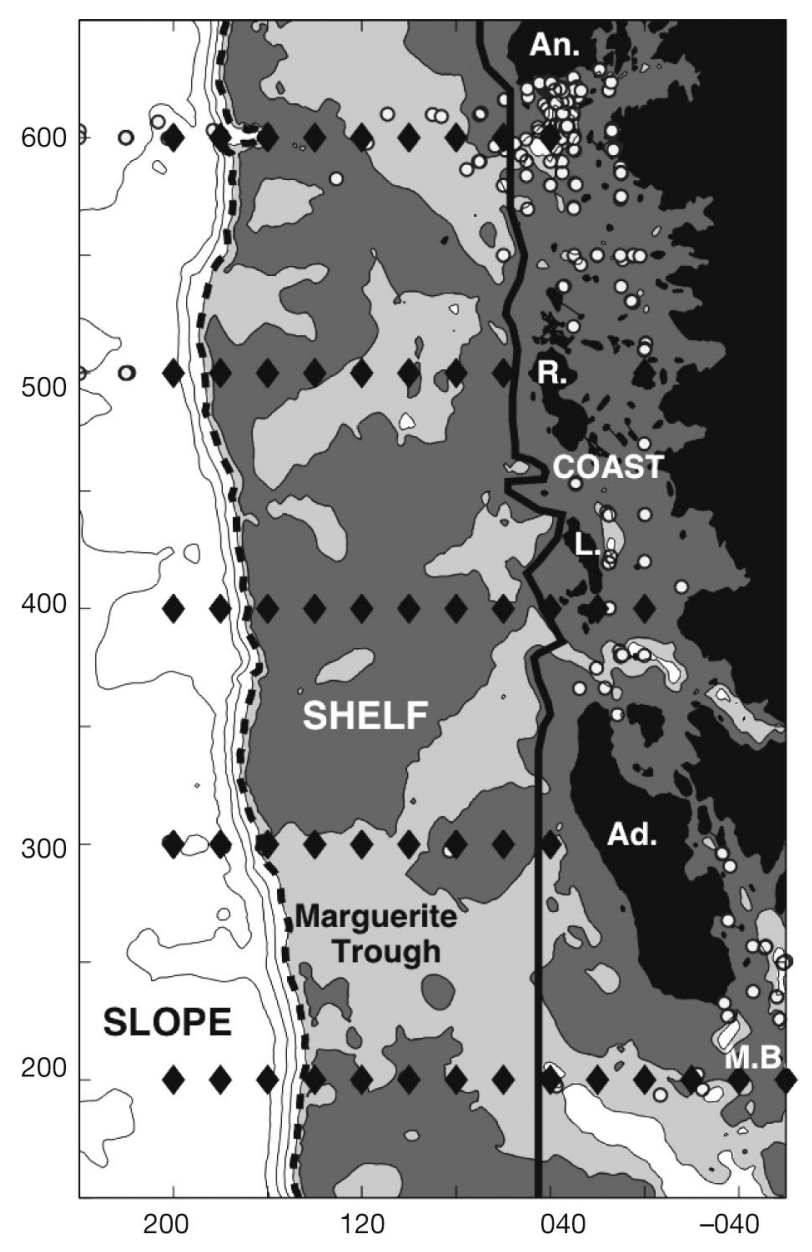

Fig. 1. Palmer LTER study region $\left(\sim 64^{\circ}\right.$ to $69^{\circ} \mathrm{S}$ and $64^{\circ}$ to $\left.74^{\circ} \mathrm{W}\right)$ with coastal, shelf and slope regions separated by lines. Islands are: An, Anvers I.; R, Renaud I.; L, Lavoisier I.; Ad, Adelaide I. MB: Marguerite Bay. Black, land mass; dark gray, $<450 \mathrm{~m}$; light gray, $\geq 450$ to $750 \mathrm{~m}$; white, $\geq 750 \mathrm{~m}$. Grid lines are labeled. Grid stations indicated with diamond, $x$-axis ${ }^{*} .240$ to ${ }^{*} .-060$, left to right. White closed circles are additional stations

MV 'Polar Duke' (1993-1997) and ARSV 'Laurence M. Gould' (1998-2008). Weather, ice, or schedules prevented sampling all stations every year (Table 1). After 2008, sampling expanded southward, with significantly decreased sampling in the original study region (600 to 200 lines). This analysis focused on the $16 \mathrm{yr}$ time series with original sampling intensity that included 3 krill population cycles. Balanced sampling within the key species' life cycle aided detection of trends and cycles. Steinberg et al. (in press) utilized these data and those from 2009 to 2013 to examine the relationship between the abundances of the major macrozooplankton taxa and environmental parameters (sea ice, atmospheric climate indices, sea surface temperature, and phytoplankton biomass 
Table 1. Cruise: year, sampling dates, grid lines surveyed, number of 'inside north' and Marguerite Bay grid cells sampled, and number of possible 46 'standard' grid cells occupied. Grid cells are equal areas centered on stations $20 \mathrm{~km}$ apart on/offshore on lines $100 \mathrm{~km}$ apart alongshore. Standard cells were those seaward of islands and outside Marguerite Bay (9 cells each on 600,400 and 300 lines, 8 cells on the 500 line, 11 cells on the 200 line). Inside north consists of 4 grid cells: 600.020, 500.000, 400.000, and 400.020. Marguerite Bay consists of 3 negative grid cells on the 200 line

\begin{tabular}{|c|c|c|c|c|c|}
\hline Cruise & $\begin{array}{l}\text { Sampling } \\
\text { dates }\end{array}$ & Grid lines & $\begin{array}{l}\text { Inside } \\
\text { north }\end{array}$ & $\begin{array}{c}\text { Marg. } \\
\text { Bay }\end{array}$ & $\begin{array}{l}\text { Std } \\
\text { stns }\end{array}$ \\
\hline 1993 & 8 Jan-6 Feb & $200(3), 300,400,500,600$ & 1 & 0 & 37 \\
\hline 1994 & 11 Jan-6 Feb & $300,400,500,600$ & 3 & 0 & 35 \\
\hline 1995 & 7 Jan-6 Feb & $200,300,400,500,600$ & 3 & 0 & 46 \\
\hline 1996 & 8 Jan-9 Feb & $200,300,400,500,600$ & 2 & $1^{\mathrm{a}}$ & 46 \\
\hline 1997 & 12 Jan-12 Feb & $200,300,400,500,600$ & 4 & 3 & 46 \\
\hline 1998 & 29 Jan-13 Feb & $200,300,400,500,600$ & 3 & 3 & 42 \\
\hline 1999 & 9 Jan-11 Feb & $200,300,400,500,600$ & 4 & 3 & 46 \\
\hline 2000 & 9 Jan-24 Jan & $200,300,400,500,600$ & 1 & 2 & 39 \\
\hline 2001 & 10 Jan-24 Jan & $200,300,400,500,600$ & 0 & 2 & 46 \\
\hline 2002 & 8 Jan-26 Jan & $200,300,400,500,600$ & 0 & 1 & 46 \\
\hline 2003 & 11 Jan-1 Feb & $200,300,400,500,600$ & 2 & 3 & 46 \\
\hline 2004 & 8 Jan-31 Jan & $200,300,400,500,600$ & 2 & 3 & 46 \\
\hline 2005 & 5 Jan-31 Jan & $200,300,400,500,600$ & 0 & 3 & 46 \\
\hline 2006 & 7 Jan-2 Feb & $200,300,400,500,600$ & 2 & 2 & 46 \\
\hline 2007 & 8 Jan-4 Feb & $200,300,400,500,600$ & 2 & 3 & 46 \\
\hline 2008 & 5 Jan-2 Feb & $200,300,400,500,600$ & 4 & 2 & 46 \\
\hline
\end{tabular}

and productivity). Due to the decreased sampling intensity beginning in 2009, the spatial scales were larger than those examined in this analysis.

\section{Collection and sample analysis}

Zooplankton were collected with a $2 \mathrm{~m}$ square net ( 700 $\mathrm{mm}$ knotless nylon square mesh) and a $1 \mathrm{~m}$ square net (335 $\mu \mathrm{m}$ Nytex mesh) towed obliquely between the surface and $120 \mathrm{~m}$ and $300 \mathrm{~m}$, respectively, as described in Ross et al. (2008). For krill and salps, the $2 \mathrm{~m}$ catch was sorted, enumerated, and abundance standardized to the volume of seawater filtered, with presence or absence noted for the $1 \mathrm{~m}$ net. Larval Pleuragramma antarcticum were enumerated for both nets. Atkinson et al. (2008) standardized net tows for Antarctic krill from multiple investigations, including the PAL LTER, to a large net towed obliquely to $200 \mathrm{~m}$, and devised corrections for the depth of the tow, time of day, size of the net, and time of year of sampling. Specifically for this study, adjustments for all but time of day were minimal and not applied. We plotted sun elevation (NOAA Solar Calculator www.esrl.noaa.gov/gmd/grad/solcalc/) for the $2 \mathrm{~m}$ net for all 3 species to test the effect of time of day on density of the catch, assuming a random distri- bution of tows over location and time of day as per Atkinson et al. (2008). Sun elevations during this study ranged from $-9^{\circ}$ to $+50^{\circ}$. A correlation of higher densities with low sun elevations would suggest either day-time avoidance of the net or migration of part or all of the population from below $120 \mathrm{~m}$ into the upper layers at low light levels. Density did not change with time of day for 2 species; linear regressions of sun elevation against density were not significant for either Antarctic krill $\left(\mathrm{n}=894, \mathrm{r}^{2}=0.0013, \mathrm{p}=\right.$ 0.284 ) or larval $P$. antarcticum $(\mathrm{n}=$ $\left.154, \mathrm{r}^{2}=0.0021, \mathrm{p}=0.577\right)$. However, for salps, densities were higher at low sun elevations. We used $5 \mathrm{yr}$ (2004-2008) of data with presence or absence of salps known for the 2 nets ( $\mathrm{n}=261$ pairs of tows at the same station) to investigate whether the 0 to 120 and 0 to $300 \mathrm{~m}$ depth horizons were coherent in detecting presence or absence of salps. The 2 nets were coherent for $77 \%$ of the pairs, and disagreed at low densities (15\% of pairs salps present in $2 \mathrm{~m}$ net, and $8 \%$ in $1 \mathrm{~m}$ net when salps absent in other net). We accepted a zero salp catch from the $2 \mathrm{~m}$ net as valid. A $3.12^{\circ}$ sun elevation was empirically determined to divide the data into 2 groups: $\leq 3.12^{\circ}$, tows done when the entire salp population was in the upper $120 \mathrm{~m}\left(\mathrm{n}=153, \mathrm{r}^{2}=0.0019, \mathrm{p}=0.589\right.$ for linear regression), and $>3.12^{\circ}$ when a portion of the salp population was between 120 and $300 \mathrm{~m}(\mathrm{n}=286$, $\mathrm{r}^{2}=0.0055, \mathrm{p}=0.209$ for linear regression). We could not distinguish the transition time with the sampling regime. The delta distribution means of the positive catches for the 2 groups were 189.8 and 36.6 zooids $10^{3} \mathrm{~m}^{-3}$ (i.e. zooids per $10^{3} \mathrm{~m}^{3}$ ), a ratio of 5.180. Density estimates of all zooids and of solitaries from all tows with initial sun elevations $>3.12^{\circ}$ were multiplied by 5.180 to standardize the data for time of day.

Abundance estimates of larval Antarctic silverfish from the $2 \mathrm{~m}$ and $1 \mathrm{~m}$ nets from the same location and day did not differ (Wilcoxon matched-pairs signedranks test, Siegel 1956) (Table 2) so data from both nets were used. Krill size distributions and salp aggregate:solitary ratios were determined for most $2 \mathrm{~m}$ catches. Size distributions of larval P. antarcticum were determined at selected stations. Details are under species description. 
Table 2. Wilcoxon matched pairs signed ranks test used to test the null hypothesis that estimates of abundance of larval Pleuragramma antarcticum from the $2 \mathrm{~m}$ and $1 \mathrm{~m}$ nets did not differ for the $5 \mathrm{yr}$ with adequate pairs of nets. $\mathrm{N}$ is the number of pairs with a difference greater than zero. $T$ is the smaller of the sum of like-signed ranks. The null hypothesis is rejected if $T$ is less than the critical value (Siegel 1956). $T^{*}$, not significantly smaller than the critical value at the $\mathrm{p}=$ 0.05 level; $\mathrm{T}^{+}$, not significant at the $\mathrm{p}=0.10$ level

\begin{tabular}{|ccc|}
\hline Year & N (pairs) & \multicolumn{1}{c|}{ T } \\
\hline 1995 & 25 & $131^{*}$ \\
1996 & 8 & $-17^{*}$ \\
2003 & 6 & $8^{*}$ \\
2007 & 16 & $-25^{+}$ \\
2008 & 8 & $8^{*}$ \\
\hline
\end{tabular}

Abundance. The study region was divided into 50 (46 standard and 4 'inside north') grid cells, each $100 \mathrm{~km}$ in the alongshore dimension, centered on grid lines and stations, and $20 \mathrm{~km}$ in the on/offshore dimension out to the ${ }^{*} .200$ cells. Inner cells were next to the continent, outer cells in waters generally 1800 to $3000 \mathrm{~m}$. Marguerite Bay cells were analyzed separately. Estimates of mean density and variance were based on the delta distribution (Aitchison 1955), as preferred for most zooplankton (Pennington 1983). The annual density for the entire grid, for individual grid lines, and for the cross-shelf gradient as represented by hydrographic regimes were calculated as in Ross et al. (2008). Means and variances for each grid cell were inspected for extremely high numbers (or variances) disproportionately affecting annual or grid-line abundances. A tow was defined as an outlier if the absolute variance was driven by that one estimate and that one estimate was an order of magnitude greater than the next highest estimate. Three tows (one each in 1993, 1998, 2002) for estimates of krill grid-wide density and one tow (1998) for krill grid-line density met these criteria. No estimates for either salps or larval $P$. antarcticum met these criteria. Frequency of occurrence was the proportion of grid cells with positive catches over the time series.

Size distribution analysis for Euphausia superba. Standard length 1 (tip of rostrum to end of uropod, Mauchline 1980) of either all krill from a tow or a random subsample of 100 krill was measured. Lengthdensity distributions (LDDs) for each cruise, the number of krill per $1000 \mathrm{~m}^{3}$ in each $1 \mathrm{~mm}$ length increment, were combined from all standard grid stations (Table 1). The program CMIX (de la Mare 1994) was used to fit a mixture of normal distributions to these cruise LDDs; outputs were observed and expected density for each length bin, calculated with
Table 3. Average standard length of AC1s from CMIX software, and upper bound length for $95 \%$ of $\mathrm{AC} 1 \mathrm{~s}$ for each year class (YC) of Euphausia superba. Standard deviations ranged from 2.123 to 3.794. Upper bound for YC2002 and YC2005 adjusted after inspection of mode shape. Data for YC1992 to 2001 from Quetin \& Ross (2003). ${ }^{*}$ Two modes of $\mathrm{AC} 1 \mathrm{~s}$ present

\begin{tabular}{|lcc|}
\hline Year class & $\begin{array}{c}\text { Ave StdL }(\mathrm{mm}) \\
\text { AC1 }\end{array}$ & $\begin{array}{c}\text { Upper bound for } \\
95 \% \text { AC1 }\end{array}$ \\
\hline 1992 & 23.04 & 28 \\
1993 & 28.29 & 34 \\
1994 & 28.20 & 35 \\
$1995^{*}$ & $17.08,23.51$ & 29 \\
1996 & 22.12 & 28 \\
1997 & 24.77 & 29 \\
1998 & 26.00 & 30 \\
$1999^{*}$ & $19.71,28.02$ & 34 \\
2000 & 25.88 & 31 \\
$2001^{*}$ & $16.75,25.35$ & 32 \\
2002 & 26.18 & 31 \\
2003 & 24.58 & 30 \\
2004 & 25.64 & 32 \\
$2005^{*}$ & $22.56,28.13$ & 33 \\
2006 & 26.99 & 33 \\
2007 & 23.12 & 29 \\
& & \\
\hline
\end{tabular}

the delta distribution, and the total density and mean total length of each mixture component. There was usually a clear mode of small krill about 1 yr old (age class $1, A C 1 \mathrm{~s})$, generally $\leq 31 \mathrm{~mm}$, and 1 to 3 modes of older age classes. Year classes (YC) were identified by the year of the summer spawned. The index of recruitment success $\left(R_{1}\right.$, proportion of the $A C 1 s$ of the total population [de la Mare 1994]) and absolute recruitment success (density of AC1s [Siegel et al. 1998]) were estimated for each year class for the entire region and for each grid line. The upper bound length for AC1s was calculated as the mean length plus 2 standard deviations (Table 3 ). $\mathrm{R}_{1}$ for a grid line was the proportion of krill smaller than this upper bound of the total krill from the line. Density of AC1s for a grid line was the mean grid-line krill density multiplied by the line-specific $\mathrm{R}_{1}$.

Population analysis for Salpa thompsoni. From 1995 to 2008 zooids were identified as either aggregates (A) or solitaries (S). Small solitaries $(\sim 10$ to $15 \mathrm{~mm}$ with some as large as $40 \mathrm{~mm}$, colorless digestive glands, often with yolk sacs) were likely released prematurely due to turbulence in the net, and were counted as embryos for 1997-2008. When possible, all solitaries were removed from the catch and measured. For large catches (>3 1), subsamples of 200 to 400 zooids were examined for aggregate:solitary $(\mathrm{A}: \mathrm{S})$ ratios. Mean number of embryos per tow and 


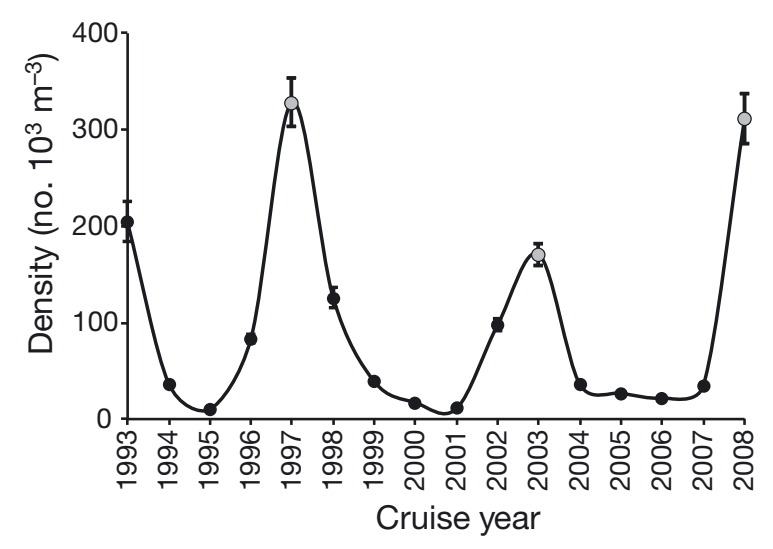

Fig. 2. Euphausia superba. Mean annual delta distribution density (ind. $10^{3} \mathrm{~m}^{-3}$ ) with standard error for the entire study region. The relationship between peak density (Year 3 of the cycle, grey circle) and time: density $(\mathrm{yr} 3)=283.42 \mathrm{e}^{-0.008 \cdot t}$ with $t$ in years since 1993, $\mathrm{r}^{2}=0.016$

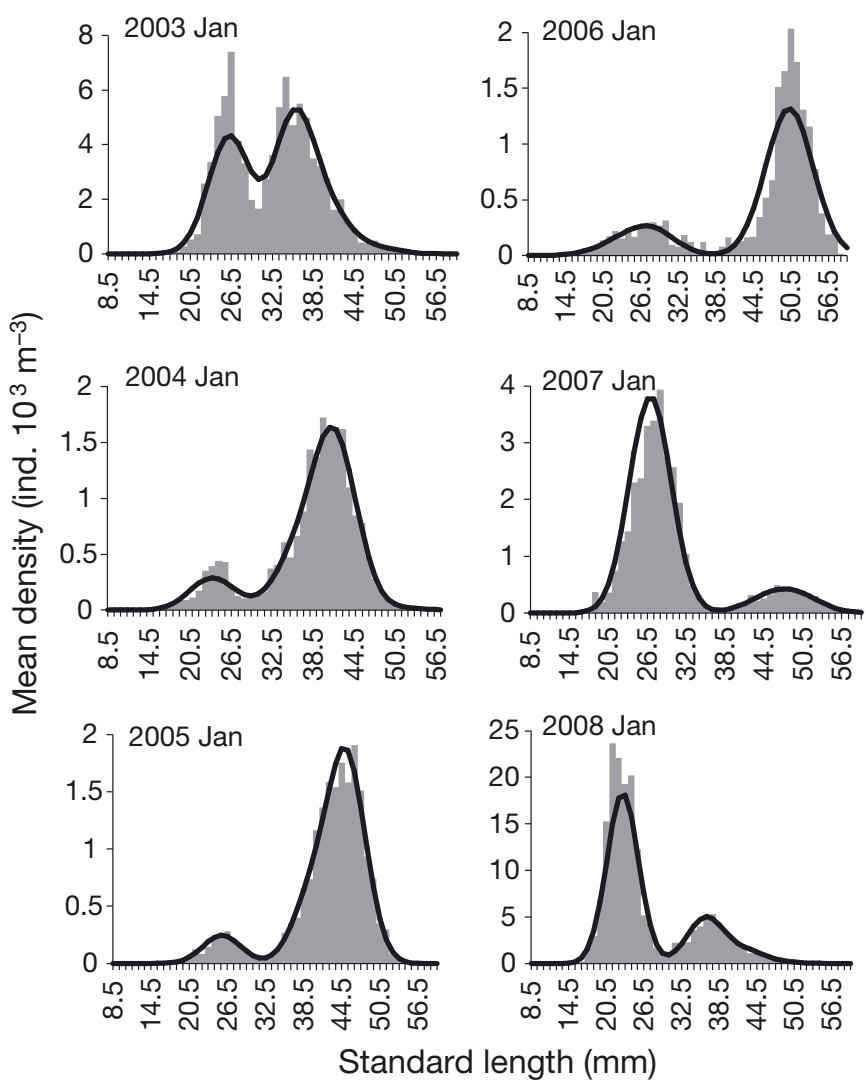

Fig. 3. Euphausia superba. Length density distributions (LDDs) for 2003-2008, with the year and month of the cruise above the LDDs. LDDs from earlier cruises in the time series are in Quetin \& Ross (2003). Length bins are $1 \mathrm{~mm}$, the number on the $x$-axis indicates the mean standard length in the bin. Bars are the average observed abundance in each length bin calculated with the delta distribution. The line represents the expected abundance as calculated with CMIX. Note changes in scale on $y$-axis the A:S ratio were used to characterize bloom progression. Large numbers of embryos indicated that aggregates were either ready to release or had released small solitary zooids.

Size distribution analysis for Pleuragramma antarcticum. Total lengths (TL) of a subsample of larval $P$. antarcticum were measured to the nearest $\mathrm{mm}$ at selected stations. Growth rates were estimated with mean TLs from 23 size distributions with $\geq 3$ individuals, 16 from 1994-1997 in the coastal waters north of Adelaide Island and 6 in 2003 from Marguerite Bay. Growth rate was the slope of average TL versus day-of-year of sampling.

Regional abundance and recruitment of Antarctic krill and abundance and A:S of salps were compared to anomalies of indices of seasonal sea ice dynamics for the region (Stammerjohn et al. 2012), and to a seasonal ENSO index (ONI, Nino3.4 anomalies, 3 mo running mean) from the NOAA website (May 2012) www.cpc.ncep.noaa.gov/products/analysis_ monitoring/ensostuff/ensoyears.shtml and standardized to historical data (1971 to 2000). The krill ENSO index pooled 5 seasons, including critical periods for reproduction (spring before and summer of spawning) and larval survival (first fall, winter and spring). For salps, ENSO indices tested were winter prior to sampling and 3 seasons pooled (winter, spring prior to and summer of sampling).

\section{RESULTS}

Mean annual abundances for both Euphausia superba and Salpa thompsoni documented spatial gradients on multiple scales: grid-wide (regional), grid-line (north to south, alongshore gradient), and cross-shelf (coastal, shelf and slope). For larval Pleuragramma antarcticum, only grid-wide and gridline mean annual abundances were available.

\section{Patterns of abundance and recruitment of Euphausia superba}

Krill showed cyclical variation in grid-wide density, with the maximum $>30$ times the minimum. Two years of increasing density (1996-1997, 2002-2003, and 2007-2008) were followed by 3 to 4 yr of decreasing density (Fig. 2). Grid-wide LDDs from 2003 through 2008 (Fig. 3) confirm a continuation of the 5 to 6 yr krill population cycle for this study region (Quetin \& Ross 2003). Climatological (mean of all years) AC1 density was $31.96 \pm 4.51$ recruits $10^{3} \mathrm{~m}^{-3}$ 


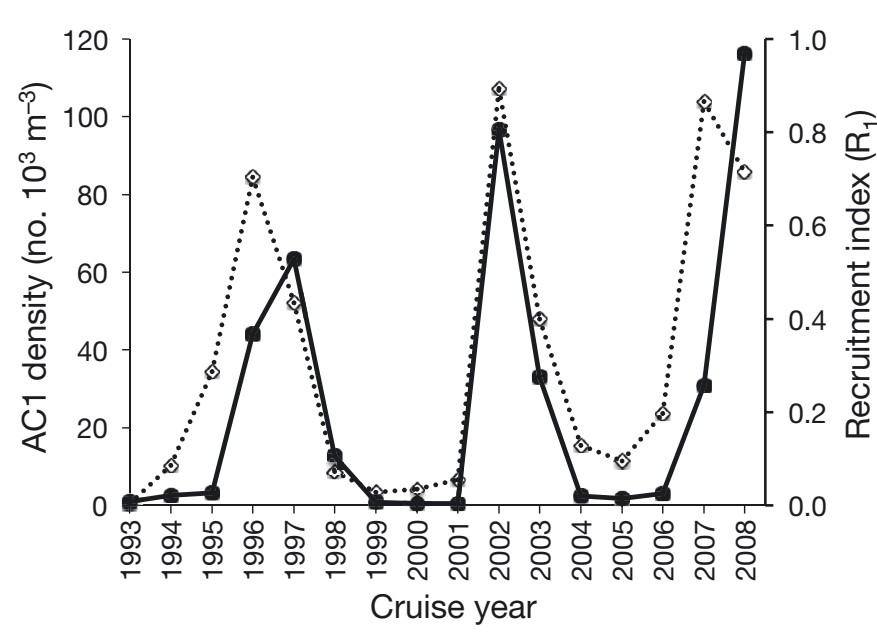

Fig. 4. Euphausia superba. Mean annual delta distribution density (ind. $10^{3} \mathrm{~m}^{-3}$ ) of age class 1 (AC1) krill (๑) and recruitment index $\left(\diamond, R_{1}\right)$ calculated with length density distributions (LDDs) and CMIX for the entire study region

(mean $\pm \mathrm{SE}$ ). Successful recruitment, defined as $\mathrm{R}_{1}>$ 0.35 and AC1 density $>30$ recruits $10^{3} \mathrm{~m}^{-3}$ occurred for 6 YCs: YC1995, YC1996, YC2001, YC2002, YC2006, and YC2007 (Fig. 4). AC1 density for successful YCs ranged from $\sim 30$ to 117 recruits $10^{3} \mathrm{~m}^{-3}$, and unsuccessful YCs from $<1$ to 13 recruits $10^{3} \mathrm{~m}^{-3}$. $R_{1}$ is a relative measure and will be higher for the 1st year of good recruitment than the 2nd year, because in the 2nd year the population is larger due to the previous year's young. This holds for all 3 cycles. However, the absolute number of recruits is a function of relative reproductive success and winter survival, so the number of recruits in Year 1 will not always be greater than in Year 2 .

With this population cycle, Year 1 (1995, 2001, 2006) is the year of the 1st strong YC (successful spawning summer and good larval survival overwinter), Year $2(1996,2002,2007)$ is the year of the 2nd strong $\mathrm{YC}$ and first summer of increased density resulting from that 1st strong YC. When 2 successful YCs are followed by 3 to 4 unsuccessful YCs, as in the PAL LTER study region, Year 3 will be the year of peak density. Peak density varied significantly $(328$, 171 and 311 ind. $10^{3} \mathrm{~m}^{-3}$ in 1997, 2003, and 2008, respectively) (Fig. 2). For a non-linear cycle, peak density can track trends in population density, and, in this study, krill did not decline significantly with time $\left(-0.8 \% \mathrm{yr}^{-1}\right.$, exponential equation).

A north to south difference was seen in the cyclical pattern (Fig. 5A-E). For the 300 to 600 lines, Year 3 of each cycle had the highest density in summer (or was equal to Year 2) within a cycle. The pattern was
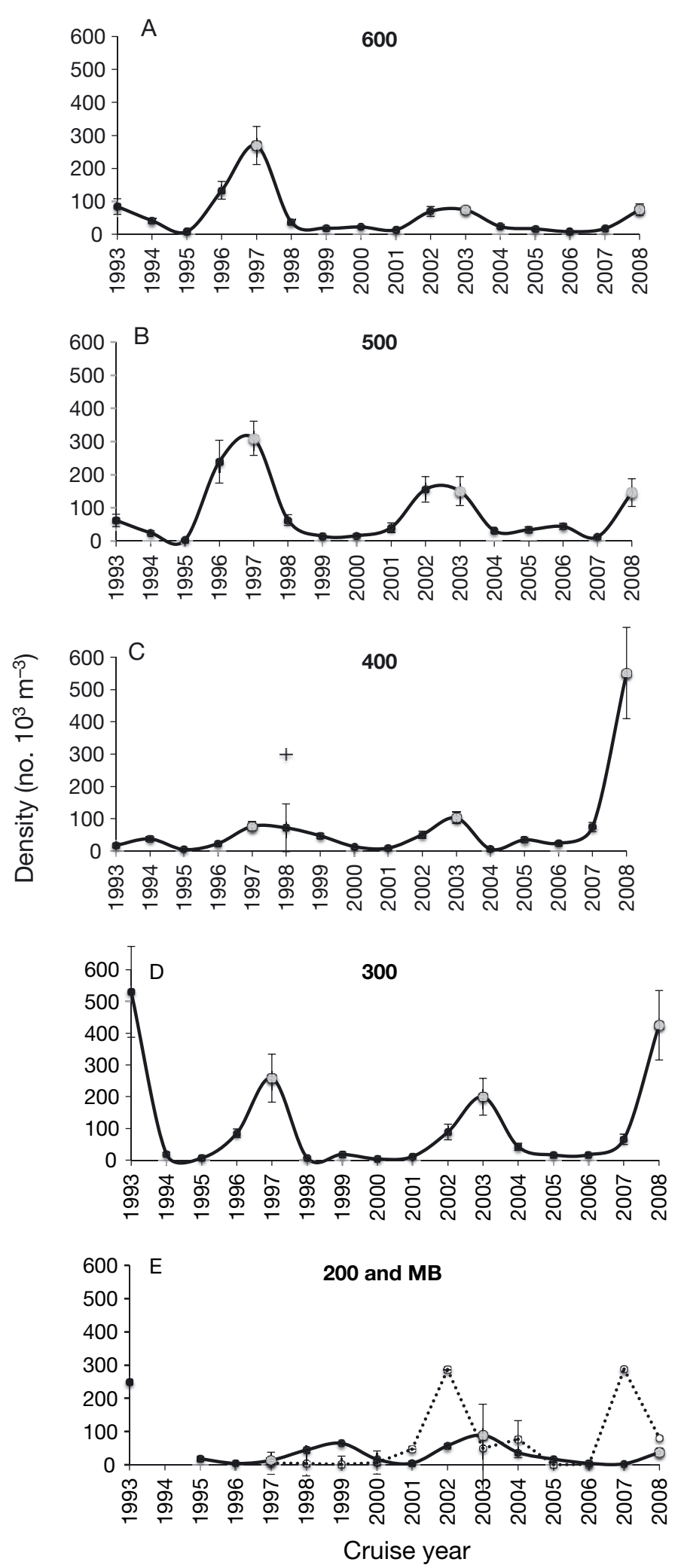

Fig. 5. Euphausia superba. Mean annual delta distribution density (ind. $10^{3} \mathrm{~m}^{-3}$ ) with standard error for each grid line. Grey circle: Year 3 of the cycle. (A) 600, (B) 500, (C) 400, + is density with grid line outlier included, (D) 300, and (E) 200 and Marguerite Bay (dotted line) 
Table 4. Exponential equations describing the increase or decrease in peak density of Euphausia superba over time for each PAL LTER grid line over the $16 \mathrm{yr}$ time series. The equation: density $(\mathrm{yr} 3)=a \mathrm{e}^{b \cdot t}$ with $t$ in years

\begin{tabular}{|lccc|}
\hline $\begin{array}{l}\text { Transect } \\
\text { line }\end{array}$ & $\begin{array}{c}a \\
\text { (ind. } 10^{3} \mathrm{~m}^{-3} \text { ) }\end{array}$ & $b$ & $\mathrm{r}^{2}$ \\
\hline 600 & 408.53 & -0.120 & 0.786 \\
500 & 400.23 & -0.070 & 0.824 \\
400 & 25.06 & +0.175 & 0.820 \\
300 & 178.25 & +0.042 & 0.368 \\
200 & 12.47 & +0.099 & 0.337 \\
\hline
\end{tabular}

irregular for the 200 line and Marguerite Bay. For the 1st cycle, highest densities in Years 2 and 3 were found on the 600 and 500 lines, for the 2nd cycle on the 500 and 300 lines, and for the 3rd cycle on the 400 and 300 lines. Between the 1st and 2nd cycles, Year 3 density decreased by 50 to $75 \%$ on the 600 and 500 lines, and slightly increased or did not change on the 300 and 400 lines. Between the 2nd and 3rd cycles, Year 3 density did not change on the 600 and 500 lines, but increased by 200 to $500 \%$ on the 300 and
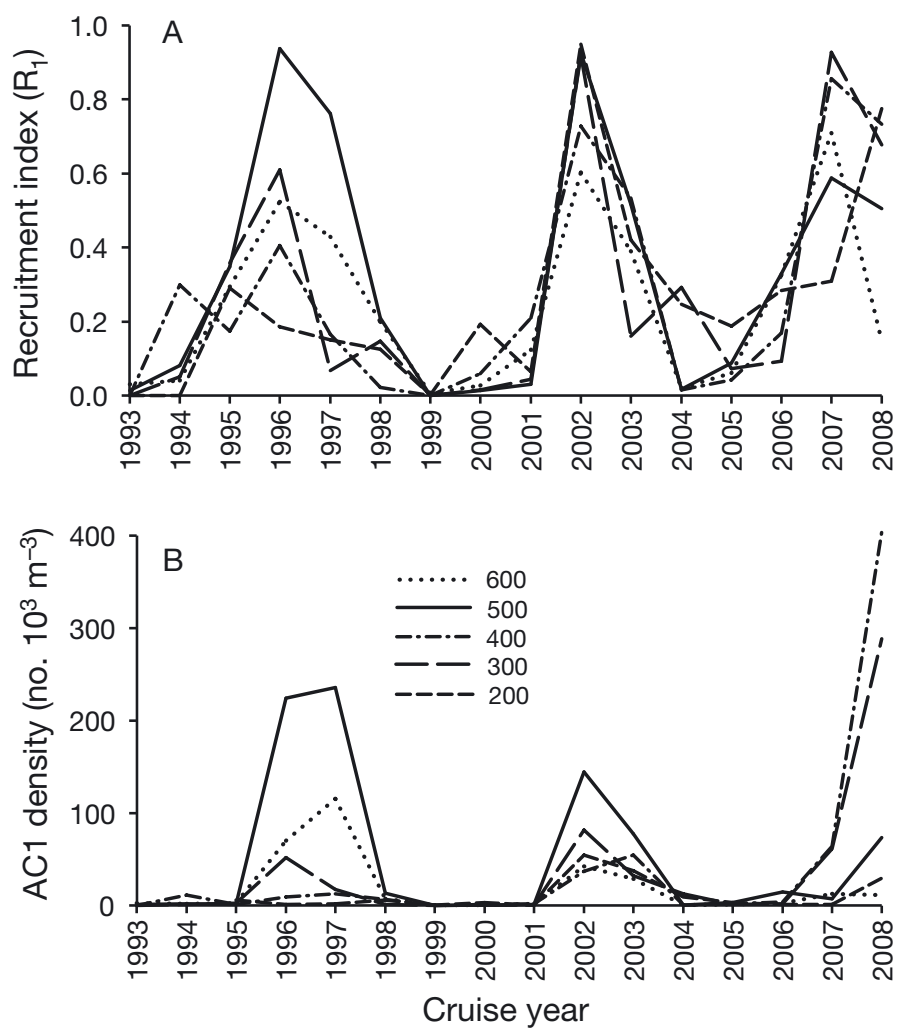

Fig. 6. Euphausia superba. (A) Recruitment index, $\mathrm{R}_{1}$, and (B) Average density of age class 1 (AC1) krill for each grid line and each cruise year calculated with the LDDs and the total length maximum for AC1 krill
400 lines. For 3 of the lines, an exponential equation described the decrease or increase in Year 3 krill densities, with an average 7 to $12 \%$ decrease on the 600 and 500 lines, and a $17.5 \%$ increase on the 400 line (Table 4). Peak density on the 300 line was high for all 3 cycles, although there was an increase for the 3rd cycle. The location where the highest densities of krill were caught shifted hundreds of kilometers southward alongshore over the $16 \mathrm{yr}$ time series. Only a minor proportion of krill were caught on the 200 line. In Marguerite Bay, krill were rare prior to 2002 (Fig. 5E).

$\mathrm{R}_{1}$ and $\mathrm{AC} 1$ densities showed the same cycle in the northern and southern parts of the grid, e.g. good recruitment regionally was reflected by elevated $R_{1} s$ on most grid lines (Fig. 6A,B), although elevated $\mathrm{R}_{1} \mathrm{~s}$ were not $>0.35$ for about $25 \%$ of the lines in 'good recruitment years' (Fig. 6A). Alongshore variability was greater for $\mathrm{AC} 1$ density than for $\mathrm{R}_{1}$. AC1 density followed the pattern for grid-line abundance, with higher AC1 densities on the 500 and 600 lines the 1st cycle, decreasing densities on the 500 and 600 lines with increasing densities on the southern 3 lines the 2nd cycle, and highest densities on the 400 and 300 lines the 3rd cycle (Fig. 6B). The shift south in the location of highest density is due to the AC1s. Highest grid-line mean AC1 densities were $>20010^{3} \mathrm{~m}^{-3}$.

The strength of the cross-shelf gradient in krill densities varied (Fig. 7), mostly due to the $>800$ fold interannual variation in coastal station densities, more than $10 \times$ greater than at shelf and slope sta-

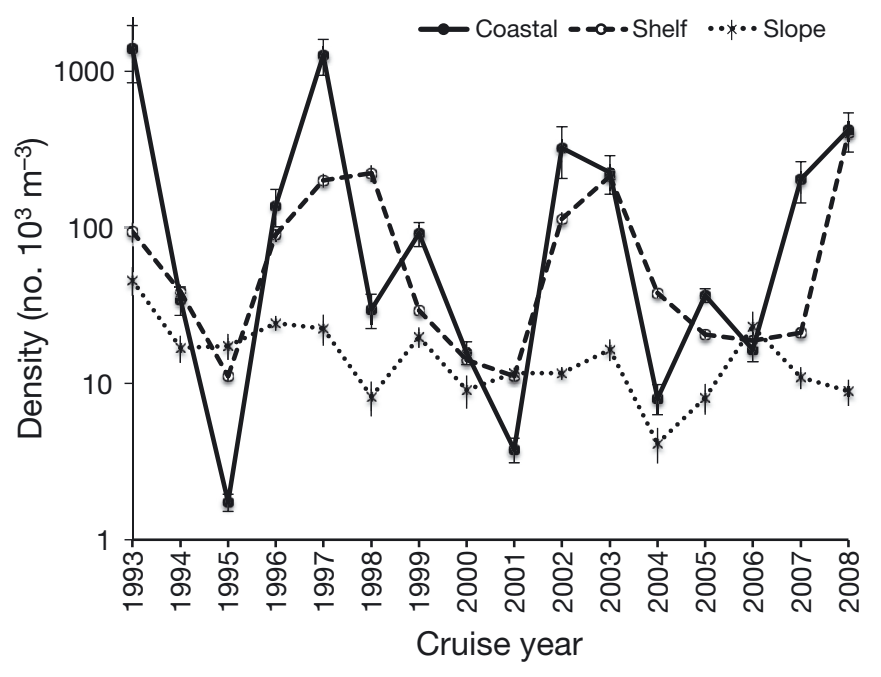

Fig. 7. Euphausia superba. Mean annual delta distribution density (ind. $10^{3} \mathrm{~m}^{-3}$ ) with standard error for hydrographic regimes within the study region: coastal $(\bullet$, solid line), shelf $(0$, dashed line), and slope ( $x$, dotted line) stations as in Fig. 1 


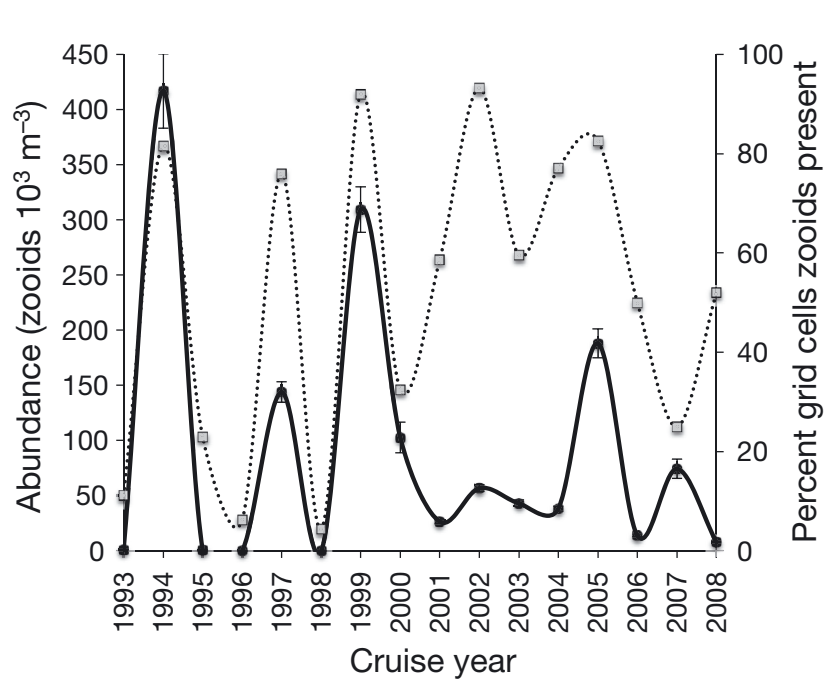

Fig. 8. Salpa thompsoni. Mean annual delta distribution density (zooids $10^{3} \mathrm{~m}^{-3}$ ) with standard error for the entire study region (•, solid line), and percent occurrence (grid cells occupied over total grid cells sampled) ( $\square$, dashed line)

tions, $\sim 36$ fold and 11 fold, respectively. A strong (coastal:slope $>10$ ) gradient was generally found in Years 2 and 3 of the population cycle. A weak (coastal:slope $<5$ ) or reverse gradient was found in years at the end and beginning of the cycle, in conjunction with low densities. From 1996-2008, the median krill density at stations seaward of the ${ }^{*} .200$ cells was 1 ind. $10^{3} \mathrm{~m}^{-3}(\mathrm{n}=45)$, an order of magnitude lower than densities at grid slope stations, 8 to 24 ind. $10^{3} \mathrm{~m}^{-3}$ (Fig. 7).

\section{Patterns of abundance and bloom dynamics of Salpa thompsoni}

Frequency of occurrence and density reflect bloom spatial extent and environmental conditions for bloom development, respectively. Climatological mean frequency of occurrence and density for the $16 \mathrm{yr}$ time series were $51.5 \%$ and 119.95 zooids $10^{3} \mathrm{~m}^{-3}$. We defined 'salp' years as high occurrence $(>75 \%)$ and moderate ( $>100$ zooids $10^{3} \mathrm{~m}^{-3}$ ) density during the cruise, i.e. 1994, 1997, 1999, and 2005 (Fig. 8). Gridwide occurrence and density were likely underestimated in 2000 as not all slope grid cells were sampled. In the first half of the time series, frequency of occurrence and zooid density were closely and positively correlated. However, after 2000, the frequency of occurrence was $>50 \%$ in all but 2007 , but density was less than the climatological mean in all but 2005 (Fig. 8).
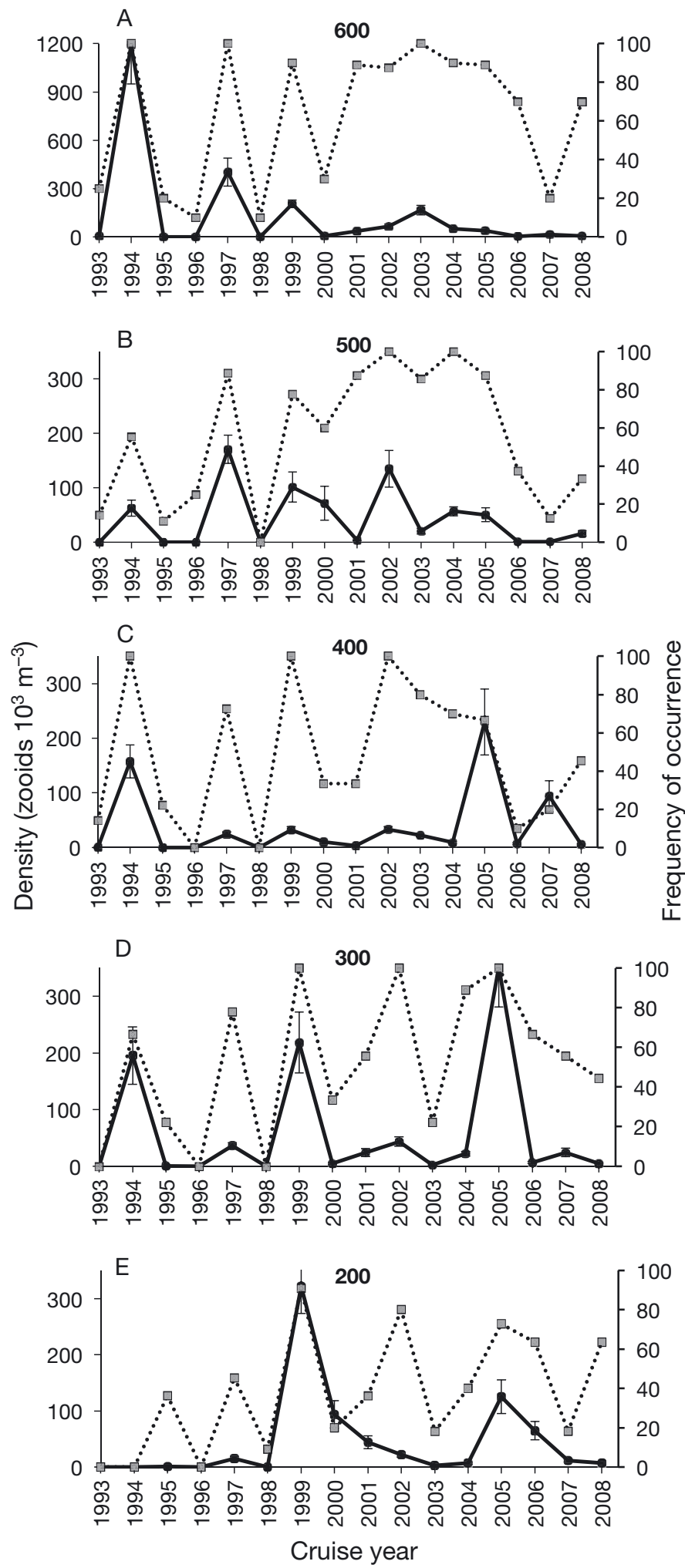

Fig. 9. Salpa thompsoni. Mean annual delta distribution density (zooids $10^{3} \mathrm{~m}^{-3}$ ) with standard error for each grid line $(\bullet$, solid line), and percent occurrence ( $\square$, dashed line). Stations in Marguerite Bay rarely included salp zooids and are not included in the figure. (A) 600, (B) 500, (C) 400, (D) 300, and (E) 200 


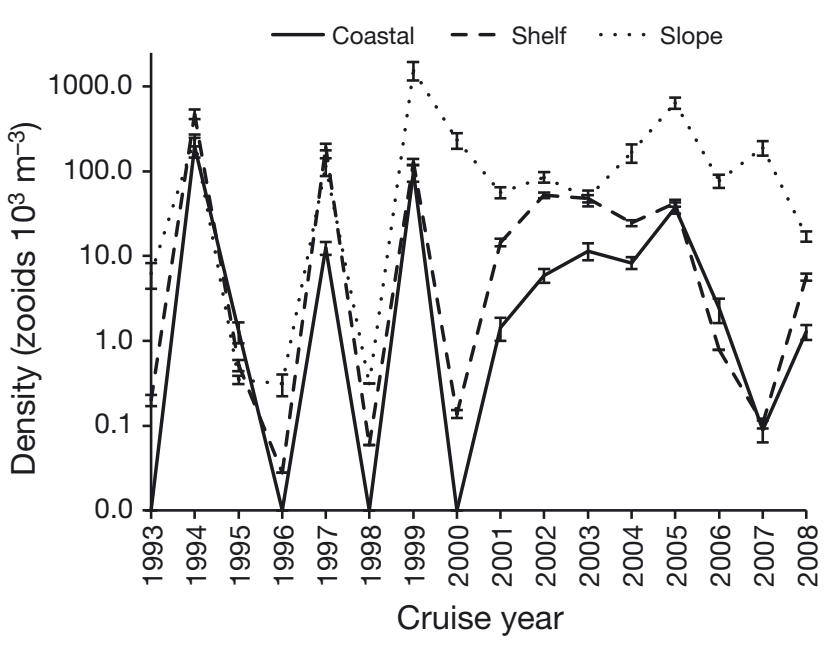

Fig. 10. Salpa thompsoni. Mean annual delta distribution density (zooids $10^{3} \mathrm{~m}^{-3}$ ) with standard error for hydrographic regimes within the study region: coastal, shelf and slope stations as in Fig. 1

Although frequency of salp occurrence for each grid line was similar to the grid-wide pattern, density patterns differed (Fig. 9). Very high densities (>300 zooids $10^{3} \mathrm{~m}^{-3}$ ) were rare in space and time (600 line in 1994 and 1997, 200 in 1999, and 300 in 2005). Elevated densities ( $>$ the mean of 120 zooids $10^{3} \mathrm{~m}^{-3}$ ) were not found on every line during salp years, with the lines closest to the cross-shelf troughs (600 and 300, Fig. 1) most consistent in elevated salp densities. After 1997, the highest densities found in 'salp' years were no longer on the 600 line but shifted south several hundred kilometers (200 to 400 lines).

Maximum densities of salps were characteristically found at slope stations, and varied interannually by a factor of 5000. Slope stations drove the overall elevated densities in 1999, 2000, and 2005 (Fig. 10). In contrast, early in the time series (1994 and 1997), both slope and shelf stations contributed to overall high densities. From 1996-2008, the median zooid density at stations seaward of *.200 was 141 zooids $10^{3} \mathrm{~m}^{-3}(\mathrm{n}=45)$, nearly twice the median density at grid slope stations (Fig. 1) during the same time period (Fig. 10).

Solitary zooids were not present at a majority of stations in any year, and average annual densities were $<1.2$ zooids $10^{3} \mathrm{~m}^{-3}$ (Table 5); highest densities were found in 1997, 1999-2002, and 2005-2006. The cross-shelf gradient for solitary densities was similar to that of aggregates, i.e. highest in slope waters and rare in coastal waters. The salp:krill ratio of gridwide densities illustrated variability in community
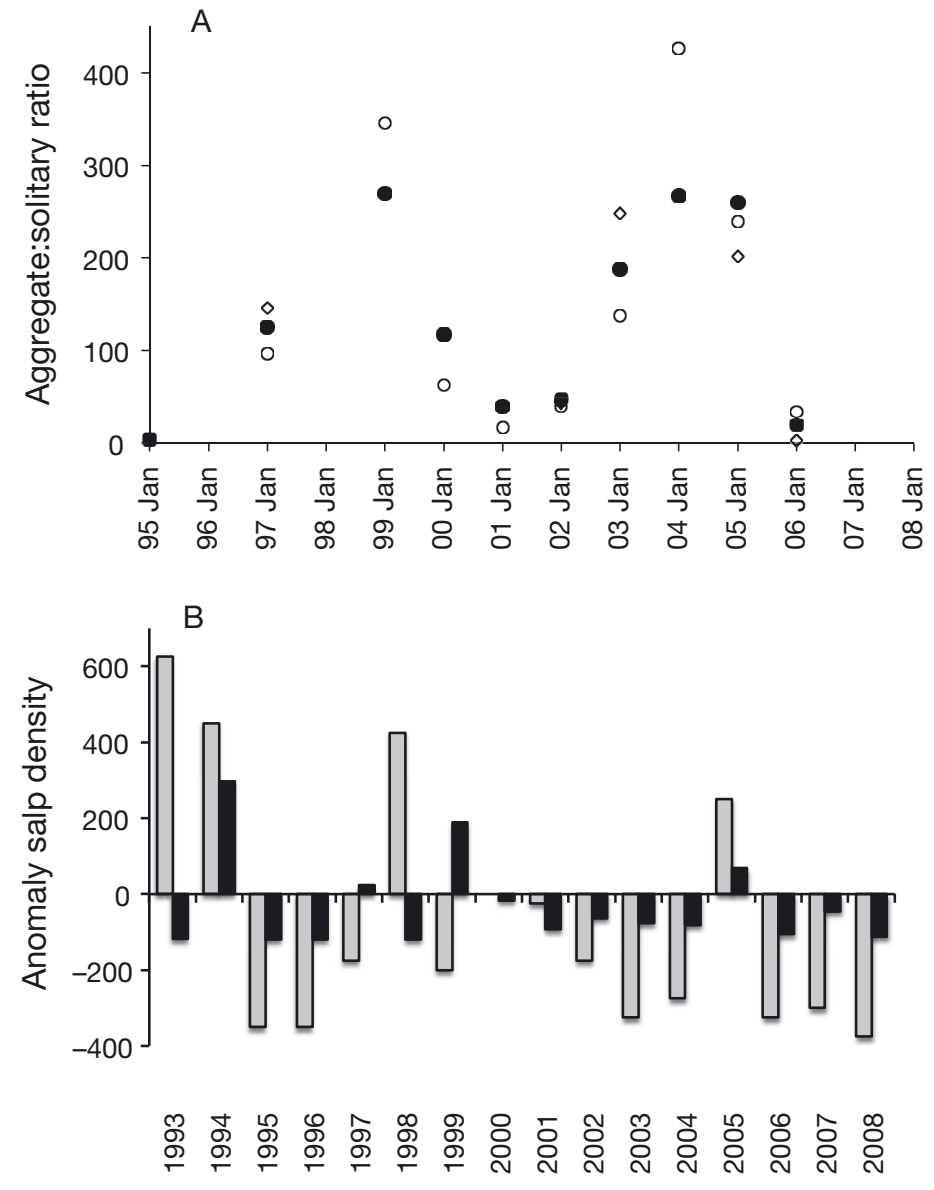

Fig. 11. Salpa thompsoni. (A) Aggregate:solitary zooid ratio, 1995-2008 annual summer cruise. 99Jan-1 indicates the ratio is based on the first sampling of the grid cells. Gridwide, closed circle; slope only, open circle; shelf only, open diamond. Due to no or few solitaries, A:S was not calculated in 1996, 1998, 2007, and 2008 for all grid cells or slope cells. For shelf stations, A:S was calculated for 5 yr (1997, 2002-2003, 2005-2006). (B) Anomaly in density relative to the mean 2003-2009 (Elephant I, Loeb \& Santora 2012) or 1993-2008 (PAL LTER, this study). Grey bar, Elephant I, Jan/Feb; black bar, PAL LTER

composition (Table 5), with ratios $<0.1$ in krilldominant years and $>6$ in salp-dominant years. Two patterns emerged: (1) the number of krill-dominant years decreased from 4 to 1 between the 1st and 2nd half of the time series; (2) salp-dominant years were in Years 5 or 6 of the krill population cycle when krill densities were at a minimum (Table 5).

Small aggregates were present all years (authors' unpubl. data) indicating that release of aggregates was ongoing in January. Solitaries were usually $\geq 55 \mathrm{~mm}$ in body length, although in 2001 and 2002 smaller, recently released solitaries (20 to $40 \mathrm{~mm}$ ) dominated. The average embryo abundance per tow 
Table 5. Ratio of grid-wide mean density of Salpa thompsoni to that of Euphausia superba for each cruise, with year within recruitment cycle of E. superba. Mean density of solitaries, number of embryos per $2 \mathrm{~m}$ tow. NaN means data not collected that year

\begin{tabular}{|ccccc|}
\hline Year & $\begin{array}{c}\text { Salp: } \\
\text { krill }\end{array}$ & $\begin{array}{c}\text { Year in krill } \\
\text { cycle }\end{array}$ & $\begin{array}{c}\text { No. solitaries } \\
10^{3} \mathrm{~m}^{-3}\end{array}$ & $\begin{array}{c}\text { No. embryos } \\
2 \text { m tow }^{-1}\end{array}$ \\
\hline 1993 & 0.01 & 4 & NaN & NaN \\
1994 & 11.36 & 5 & NaN & NaN \\
1995 & 0.06 & 1 & 0.126 & NaN \\
1996 & 0.00 & 2 & 0 & NaN \\
1997 & 0.44 & 3 & 1.138 & 29.1 \\
1998 & 0.00 & 4 & 0.003 & 2.0 \\
1999 & 7.97 & 5 & 1.143 & 67.7 \\
2000 & 6.04 & 6 & 0.870 & 0.4 \\
2001 & 2.38 & 1 & 0.647 & 6.9 \\
2002 & 0.54 & 2 & 1.191 & 2.2 \\
2003 & 0.25 & 3 & 0.228 & 0.5 \\
2004 & 1.08 & 4 & 0.143 & 3.3 \\
2005 & 6.99 & 5 & 0.721 & 9.1 \\
2006 & 0.64 & 1 & 0.671 & 0.1 \\
2007 & 2.13 & 2 & 0.005 & 0.03 \\
2008 & 0.03 & 3 & 0.029 & 0.3 \\
& & & & \\
\hline
\end{tabular}

(Table 5) was highest in 'salp' years (Fig. 8), although generally elevated between 1999 and 2005.

The A:S ratio was not calculated when $<6$ solitaries were found during the cruise (1996, 1998, 2007, 2008). The maximum A:S ratio was in 1999, and the lowest ratio in 1995 (Fig. 11A). A:S ratios $\geq 125$ were found in the 'salp' years of 1997, 1999, and 2005 (Fig. 8, Fig. 11A), and in 2 non-salp years $(2003$ and $2004)$ when densities of both aggregates $(<43$ zooids $\left.10^{3} \mathrm{~m}^{-3}\right)$ and solitaries $\left(<0.23\right.$ zooids $10^{3} \mathrm{~m}^{-3}$ ) were relatively low. Although the A:S ratio was often cor- related with density, this ratio is primarily an index of bloom dynamics. Theoretically, A:S ratios will be $>50$ when production of chains has just begun (beginning bloom), reach a maximum of $\sim 800$ at highest abundances, and be $<15$ during winter. Several succession phases exist: early stage of aggregate chain release $(1995,1996,1998)$ with few solitaries or embryos and a low A:S ratio; bloom underway $(2001,2002)$ with variable A:S ratios and solitary densities and moderate abundance of embryos; and a well-developed bloom $(1997,1999,2005)$ with A:S ratios $>125$ and numerous embryos. All 'early stage' years were before 2000 and the shift in frequency of occurrence. When comparisons were possible, the A:S ratios for the entire grid and the slope and shelf regions were similar (Fig. 11A), suggesting that salp bloom dynamics were consistent cross-shelf in any one year.

\section{Patterns of abundance of larval Pleuragramma antarcticum}

Larval $P$. antarcticum was never found at slope or outer shelf PAL LTER stations during the time series (Table 6). Inner shelf and coastal grid cells contained larval $P$. antarcticum, with the highest frequency of occurrence at coastal stations and inside Marguerite Bay. Climatological grid-cell density and annual mean grid-line densities were calculated for possible habitat, i.e. with data from grid cells where larval $P$. antarcticum occurred at least once. Climatological densities were highest at coastal stations and inside Marguerite Bay, although the inner shelf grid cells in the far north (600) and far south (200) also had high densities (Table 7).

Table 6. Proportion of annual summer cruises from 1993-2008 with larval Pleuragramma antarcticum present in a grid cell. Grid cells identified with station and line of center of cell, and as slope, shelf, or coastal according to Martinson et al. (2008). Vertical black lines separate the on/offshore zones. Grid stations 040 to 200 were sampled on the 600, 500, 400, 300 grid lines for all years $(\mathrm{n}=16)$. Grid stations 000 to 200 on the 200 line were sampled from 1995 to 2008 ( $\mathrm{n}=14)$, and inside Marguerite Bay (200.* negative cells) from 1997 to 2008 ( $\mathrm{n}=12$ ). 'Inside north' (grid cells east of the Biscoe Islands) ${ }^{\mathrm{a}}$ were not sampled every year due to ice and time constraints. Land means not sampled due to land mass

\begin{tabular}{|c|c|c|c|c|c|c|c|c|c|c|c|c|c|c|}
\hline $\begin{array}{l}\text { Sta/ } \\
\text { line }\end{array}$ & 200 & $e^{180}$ & \multicolumn{6}{|c|}{ Shelf } & 040 & 020 & $\begin{array}{l}000 \\
\text { Coa }\end{array}$ & $\begin{array}{l}-020 \\
\text { tal }\end{array}$ & -040 & -060 \\
\hline 600 & 0 & 0 & 0 & 0 & 0.063 & 0.188 & 0.250 & 0.250 & 0.438 & 0.500 & Lan & Lar & Land & Land \\
\hline 500 & 0 & 0 & 0 & 0 & 0.063 & 0 & 0.125 & 0.063 & Land & Land & 0.500 & $\mathrm{La}$ & Land & Land \\
\hline 400 & 0 & 0 & 0 & 0.063 & 0 & 0.063 & 0.063 & 0.125 & 0.063 & 0.750 & 0.333 & Land & Land & Land \\
\hline 300 & 0 & 0 & 0 & 0 & 0 & 0 & 0 & 0.188 & 0.750 & Land & Land & Land & Land & Land \\
\hline 200 & 0 & 0 & 0 & 0.071 & 0 & 0 & 0.067 & 0.286 & 0.333 & 0.500 & 0.286 & 0.583 & 0.818 & 0.857 \\
\hline
\end{tabular}

anside north: $600.020(\mathrm{n}=12,1994-2000,2003-04,2006-08), 500.000(\mathrm{n}=6,1994-95,1997-99,2008), 400.000(\mathrm{n}=3,1997$, $1998,2008), 400.020$ ( $\mathrm{n}=12,1993-99,2003-04,2006-08)$ 
Table 7. Climatology of larval Pleuragramma antarctium: Mean density $\left(1000 \times\right.$ ind. $\left.\mathrm{m}^{-2}\right)$ in each grid cell from the annual summer cruises 1993-2008. Labels and number of samples as for Table 6

\begin{tabular}{|c|c|c|c|c|c|c|c|c|c|c|c|c|c|c|}
\hline \multirow{2}{*}{$\begin{array}{l}\text { Sta/ } \\
\text { line }\end{array}$} & 200 & 180 & 160 & 140 & 120 & 100 & 080 & 060 & 040 & 020 & 000 & -020 & -040 & -060 \\
\hline & \multicolumn{2}{|c|}{ Slope } & \multicolumn{6}{|c|}{ Shelf } & \multicolumn{6}{|c|}{ Coastal } \\
\hline 600 & 0 & 0 & 0 & 0 & 2.41 & 34.64 & 19.70 & 101.3 & 320.6 & 432.4 & Land & Land & Land & Land \\
\hline 500 & 0 & 0 & 0 & 0 & 6.62 & 0 & 4.35 & 7.34 & Land & Land & 869.0 & Land & Land & Land \\
\hline 400 & 0 & 0 & 0 & 6.33 & 0 & 5.08 & 19.03 & 17.57 & 9.78 & 149.2 & 89.83 & Land & Land & Land \\
\hline 300 & 0 & 0 & 0 & 0 & 0 & 0 & 0 & \begin{tabular}{|l|}
3.90 \\
\end{tabular} & 71.91 & Land & Land & Land & Land & Land \\
\hline 200 & 0 & 0 & 0 & 0.71 & 0 & 0 & 0.79 & 227.8 & 74.15 & 14.77 & 22.97 & 146.9 & 688.4 & 2019.7 \\
\hline
\end{tabular}

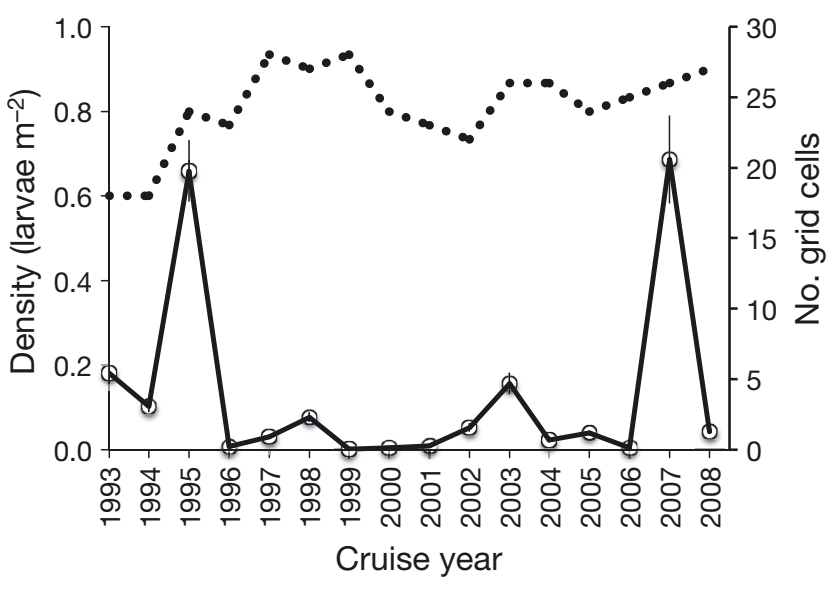

Fig. 12. Larval Pleuragramma antarcticum. Mean annual delta distribution density (larvae $\left.\mathrm{m}^{-2}\right)(0$, solid line) with standard error for the coastal and inner shelf habitat (only 2 habitats where larval $P$. antarcticum ever found in study region) plus 3 stations in Marguerite Bay from 1997. Dotted line is number of grid cells of defined habitat sampled each year

In most years, mean larval density was < 0.1 larvae $\mathrm{m}^{-2}$; highest densities occurred in 1995 and 2007 (Fig. 12). Marguerite Bay was not sampled in the first 4 yr, thus peaks in 1993 and 1995 may be underestimates. Although interannual variability in density of larval $P$. antarcticum is large, implying large variability in recruitment success, there is not a clear pattern nor is there an association with either krill or salps.

The region of highest density of larval $P$. antarcticum shifted during the study period (Fig. 13). In the northern part of the study region (Fig. 13A), larval $P$. antarcticum was found further offshore (to ${ }^{*} .120$ ) than on most lines (Table 7), but high densities (max 1.83 larvae $\mathrm{m}^{-2}$ ) were only found early in the time series (1993-1995, 1997). Larval P. antarcticum has not been found in the northern part of region since January 2000. In the mid-study region, densities were lower (Fig. 13B), although larval P. antarcticum persisted behind Lavoisier Island throughout the study period. On the 200 line, mean densities of lar-
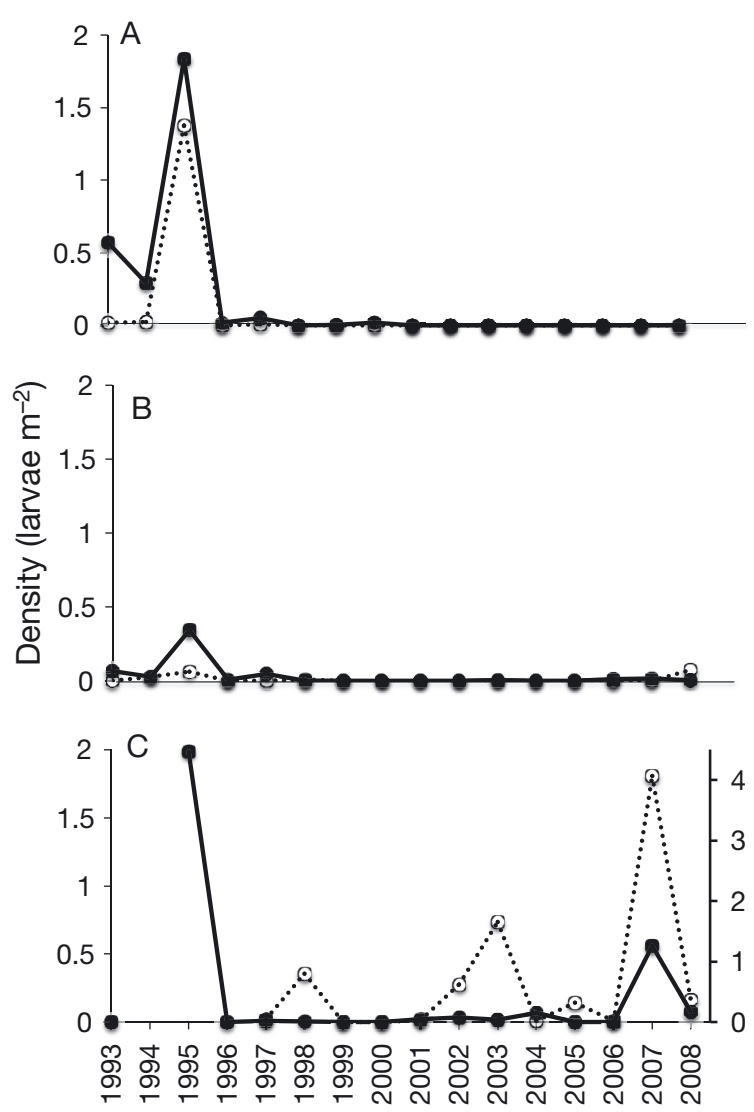

Fig. 13. Larval Pleuragramma antarcticum. Mean annual density (larvae $\mathrm{m}^{-2}$ ) for grid cells on each grid line within habitat. (A) northern grid lines: 600 (solid line), 500 (dashed line); (B) mid-region grid lines: 400 (solid line), 300 (dashed line); (C) southern grid line: 200 (outside Marguerite Bay, solid line), inside Marguerite Bay (dashed line, sampled routinely from 1997). Note different density scale on right for $y$-axis for Marguerite Bay

val $P$. antarcticum at inner shelf and coastal stations were the same or higher than densities in the midand northern regions early in the time series, and Marguerite Bay densities were the highest of any area, up to 4.06 larvae $\mathrm{m}^{-2}$ in 2007 (Fig. 13C). Peak grid-wide density in 1995 was due to larvae from the northern 2 lines and just outside Marguerite Bay, 


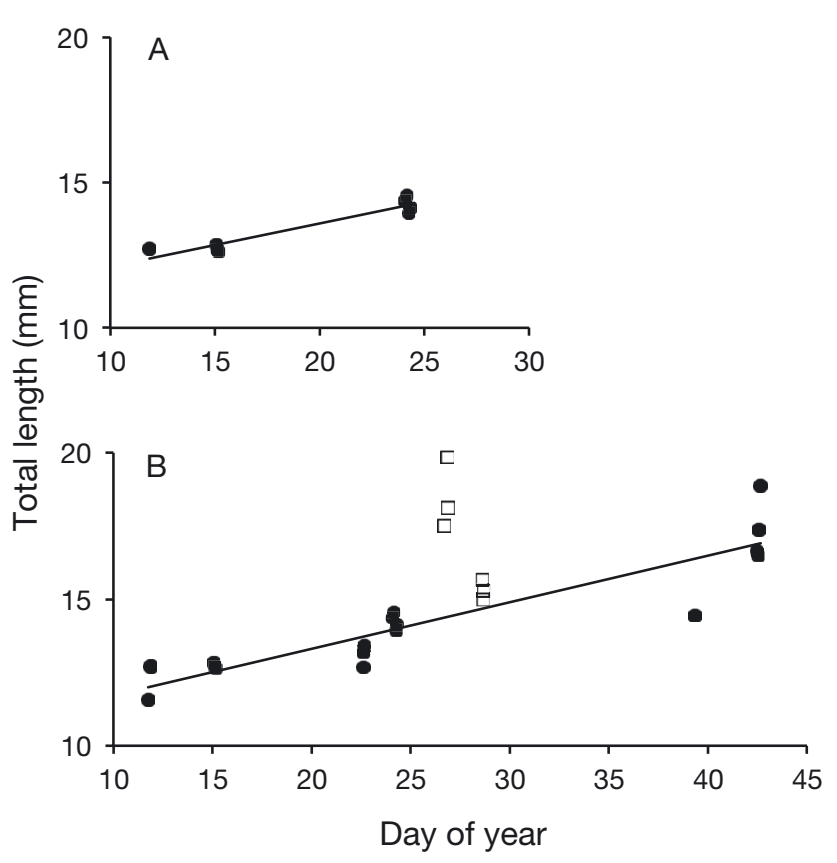

Fig. 14. Larval Pleuragramma antarcticum. Total length (mm, TL) as a function of Day of year: (A) 95Jan, TL $=0.149 \times$ $\mathrm{DoY}+10.62, \mathrm{r}^{2}=0.91$; (B) 1994-1997 (•), TL $=0.159 \times$ DoY + 10.13, $\mathrm{r}^{2}=0.83$; Marguerite Bay, 2003 (ㅁ)

whereas in 2007 peak density was due to Marguerite Bay. Elevated densities have been restricted to the southern region since 1998, although a few larval $P$. antarcticum were found recently at coastal stations from within Marguerite Bay north to the 400 line.

\section{Larval Pleuragramma antarcticum growth rates}

Growth rates calculated from samples from the 600 line in 1995 (Fig. 14A) and from all samples from the 400 to 600 lines between 1994-1997 (Fig. 14B) were $0.15 \mathrm{~mm} \mathrm{~d}^{-1}$ and $0.16 \mathrm{~mm} \mathrm{~d}^{-1}$, respectively. Larvae collected in 2003 in Marguerite Bay varied from 15.00 to $19.85 \mathrm{~mm}$ in $\mathrm{TL}$, and were not used in growth rate calculations due to the short time period ( $2 \mathrm{~d}$ ) and geographical separation.

\section{Seasonal sea ice dynamics and teleconnections to the ENSO cycle for salps and krill}

A Spearman's rank correlation (Siegel 1956) was used to evaluate correlations among anomalies of ice retreat, advance, and duration in the wAP (Stammerjohn et al. 2012) and grid-wide krill abundance and recruitment and salp abundance. For krill, only $\mathrm{R}_{1}$

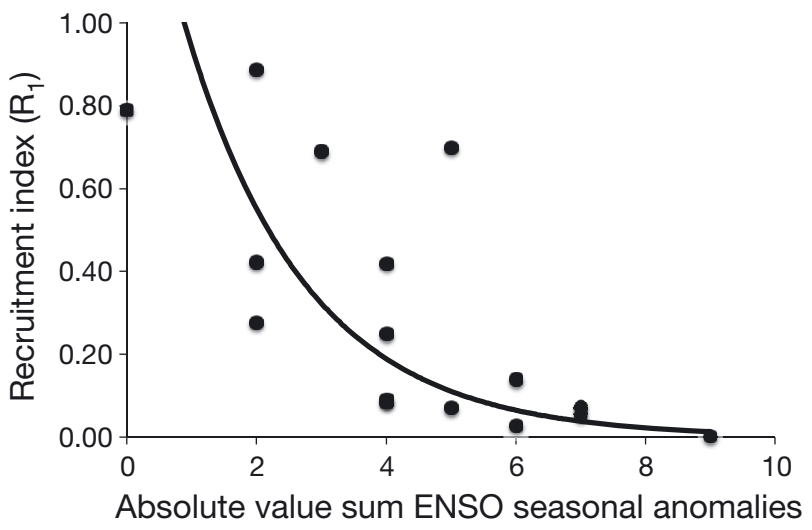

Fig. 15. Euphausia superba teleconnection with ENSO. $\mathrm{R}_{1}$ as a function of the absolute value of the sum of the ENSO seasonal sea surface temperature anomalies for the 5 seasons from the spring before spawning through the following spring when larvae are $1 \mathrm{yr}$ old $\left(\mathrm{R}_{1}=1.605\right.$ $\left.\mathrm{e}^{-0.535 \cdot(\text { absol-sumENSO) }}, \mathrm{r}^{2}=0.67\right)$. Seasonal anomalies $(3 \mathrm{mo}$ running mean) are based on the $30 \mathrm{yr}$ period 1971 to 2000 (ONI)

and the retreat anomaly were significantly correlated $\left(r_{S}=0.49, p=0.05\right.$ one tailed $)$; the $r_{S}$ for advance and duration anomalies and recruitment were $<0.31$. The $\mathrm{r}_{\mathrm{S}}$ values for all ice anomalies and krill abundance were $<0.08$ (critical value for significance $=0.425$ ), a lack of correlation similar to that found by Ross et al. (2008). For salps, the $\mathrm{r}_{\mathrm{S}}$ values for all anomalies and abundance were between 0 and -0.28 . We predicted that higher A:S would be found in January after an early retreat as the warmer surface waters would promote growth; however, the correlation between A:S and ice retreat anomaly was not significant $\left(\mathrm{r}_{\mathrm{S}}=0.445\right.$, critical value $\left.=0.564\right)$. Early ice retreat alone is not sufficient for an advanced bloom by January. Thus, grid-wide parameters for these 2 species did not show consistent associations with any single regional sea ice index.

Given the known teleconnections between ENSO and sea ice, we previously developed a multi-season ENSO index to sum the effects of multiple seasons. The exponential relationship between successful recruitment and neutral or low absolute ENSO indices for the previous 15 mo found for the first half of the time series (Quetin \& Ross 2003) continued, with lowest recruitment indices found during strong El Niño or La Niña 15 mo time periods (Fig. 15). Salp density in the study region was not correlated with the ENSO cycle (Spearman's rank correlation: density versus the ONI [Oceanic Niño Index] for the prior winter $[\mathrm{r}=-0.1]$; density versus the sum of the ONI for the previous winter, spring, and summer of observation $[\mathrm{r}=-0.12])$. 


\section{DISCUSSION}

In the wAP, variability in physical processes allows testing of the hypothesis that structure and function of the Antarctic marine system are strongly influenced by physical processes, in particular annual advance and retreat of sea ice (Smith et al. 1995). The summer sampling region for the PAL LTER covers a large part of the slow, cyclonic gyre with 2 or 3 circulation cells known for the region (Stein 1988). One question concerns how well the defined study region encompassed the habitats of the 3 species discussed here.

\section{Sampling location and design}

Krill are at the boundary between plankton and nekton, with adults viewed as micronekton and larvae as zooplankton. Nicol (2006) suggested that krill's swimming and chemosensory abilities and behavioral patterns might foster its retention within favorable habitats. With a retention system, the effects of the local physical and biological environment on the population dynamics of largely local krill stocks better explain distribution and abundance than advection. Several studies support the PAL LTER region as a retention system: regional YC success is correlated with regional environmental characteristics (Quetin \& Ross 2003); the assumption of zero transport of larval krill away from the region is reasonable (Wiedenmann et al. 2009); and larval krill are predominantly retained in winter on the shelf (Piñones et al. 2011, 2013). Thus, the gyre system of the PAL LTER (Smith et al. 1999, Martinson et al. 2008 ) is viewed as a larval retention region, with a largely local adult population. Larvae hatched from embryos released by adult females on the outer shelf and slope are retained in the same region as the adults.

Although $87 \%$ of the circumpolar krill population are in waters deeper than $2000 \mathrm{~m}$, near the WAP, high densities are closer inshore on the shelf, with the oceanic habitat containing few krill (Atkinson et al. 2008). This earlier finding was supported by the sharp decrease in krill density seaward of the PAL LTER grid. In the wAP in summer, juveniles and subadults are generally on the inner shelf (Siegel 1988, Lascara et al. 1999), linked with high food concentrations (Atkinson et al. 2006, Tarling et al. 2006). Reproducing adults are on the outer shelf and slope, with underlying UCDW (Quetin \& Ross 2001, Hofmann \& Husrevoglu 2003). The cross-shelf gradient here is similar to previous studies (Siegel 1988, Lascara et al. 1999, Ross et al. 2008), with highest densities inshore, but the strength of the gradient is influenced by the krill population cycle. The varying needs of different life cycle stages can create demographic separation (Siegel 2005).

The 0 to $120 \mathrm{~m}$ depth horizon for the $2 \mathrm{~m}$ net was based on distributions of krill aggregations in 2 studies done in the area. Ross et al. (1996), in a non-quantitative acoustic study, observed krill aggregations in the upper $120 \mathrm{~m}$ of the water column with median depths 9 to $55 \mathrm{~m}$. In quantitative acoustic surveys during 4 Palmer LTER cruises, all aggregations were above $110 \mathrm{~m}$, and biomass concentrated in the upper $50 \mathrm{~m}$ (Lascara et al. 1999). The lack of a time-of-day effect on density estimates of krill at these latitudes supports the acoustic evidence that the 0 to $120 \mathrm{~m}$ depth horizon in summer includes most of the krill in the water column. Higher latitudes for PAL LTER tows likely underlie the lack of a time-of-day effect, in contrast to that found at lower latitudes (Atkinson et al. 2008). The lower light contrast due to the relatively high sun elevations may be an inadequate signal to cause detectable time-of-day differences in net avoidance as found at lower latitudes (Everson \& Bone 1986) or to trigger strong diel vertical migrations (DVM).

Antarctic krill have been found feeding on the shallow sea bed (Kawaguchi et al. 1986) and more recently in waters $>3500 \mathrm{~m}$ feeding on phytoplankton detritus (Clarke \& Tyler 2008). Schmidt et al. (2011) found between 2 and $20 \%$ of the krill population was below $200 \mathrm{~m}$, with lower percentages ( 2 to $8.5 \%)$ characteristic of shelf populations $(<500 \mathrm{~m})$. Thus, we possibly missed a small percentage of the adult Antarctic krill population by not towing close to the sea bed.

In an extensive discussion of sampling for Antarctic krill, Atkinson et al. (2012) discussed the advantages and disadvantages of nets versus acoustics. Estimates from nets adjusted as per Atkinson et al. (2008) were similar to the mean acoustic biomass estimated at the same time in the same location. Net estimates of biomass may be an underestimate due to avoidance and patchiness, but technical issues with acoustical techniques (separating krill from other sound scatterers and changing krill target strengths) also create uncertainties in acoustic biomass estimates. The $2 \mathrm{~m}$ net data provide relative density estimates from a consistent sampling regime that includes habitats for all demographic groups, allows us to detect trends and cycles, and to investigate possible mechanisms underlying any change detected. 
In contrast, the sampling design does not include the entire horizontal or vertical range for Salpa thompsoni. Historically, salps had rarely been found within the study region. Both the strong cross-shelf gradient with maximum densities at slope stations and median zooid densities at offshore stations twice that of slope stations suggested a source population in the ACC. In addition, $S$. thompsoni is known to show both an ontogenetic (Foxton 1966) and diel vertical migration (Casareto \& Nemoto 1986, Perissinotto \& Pakhomov 1998, Nishikawa \& Tsuda 2001), with a significant proportion of the salp population between 90 and $300 \mathrm{~m}$ during the day. Nishikawa \& Tsuda (2001) noted that upward migration for the DVM of salps at their $64^{\circ} \mathrm{S}$ study site began during midday, but the population remained at 30 to $120 \mathrm{~m}$ for a relatively long time before reaching the surface at complete darkness. The 0 to $120 \mathrm{~m}$ depth horizon for the $2 \mathrm{~m}$ net of this study appeared to include $<20 \%$ of the salps in the water column during daylight hours. We viewed the patterns of salp abundance as a function of when and where the ACC and resident salps or seed populations moved closer to the shelf break and were included in the annual sampling. With a seasonal life cycle, the bloom progression found in the salps may be a response to local physical and biological environments, but sampling was not designed to investigate the full habitat range.

For Pleuragramma antarcticum, we sampled only the larval habitat, e.g. the upper water column in cold continental shelf waters (La Mesa \& Eastman 2012). In contrast to Antarctic krill and salps, found in all grid cells in some years, larval $P$. antarcticum were restricted to inner shelf and coastal waters, especially Marguerite Bay. Larval distributions were considered the source of possible future prey for predators.

\section{Impact of environmental changes}

Variability in abundance and distribution of these pelagic species may be due to changes in population dynamics (birth and death rates), behavioral responses, or circulation patterns (Flores et al. 2012a). With climate warming and increases in ocean temperature, Mackey et al. (2012) predicted southward shifts in distributions of many Antarctic zooplankton, although Quetin et al. (2007) added the caveat that habitat extension southward may be limited by latitudinal changes in light regime and energy input interacting with life cycle phenology.
At the spatial scale of the $100000 \mathrm{~km}^{2}$ study region, densities of Antarctic krill followed a 5 to 6 yr population cycle with highest densities after 2 sequential years of successful recruitment. Peak density varied, but did not decline monotonically. In contrast, the pattern of frequency of occurrence and density of $S$. thompsoni shifted in 2000. Salps now are consistently found on the shelf, but high densities characteristic of a 'salp' year are less frequent. Interannual variability in grid-wide densities of larval $P$. antarcticum was also high (factor $>600$ ), with no clear cycle or trend. The 2 yr of highest density were 12 yr apart, affecting our ability to detect a long cycle.

At the finer spatial scale, i.e. the alongshore or north to south gradient, highest densities of all 3 species were found further south over time. For krill, densities found during the peak year of the population cycle decreased on the northern lines and increased $200 \mathrm{~km}$ to the south. The initial climatology for $S$. thompsoni showed a pattern shaped like a small ' $r$ ', with densities 2 orders of magnitude greater on the slope and northern shelf regions (Ross et al. 2008). Positive anomalies in abundance were found in the southern slope region from 1999-2001, at the time of the pattern change. With the full 16 yr time series, the highest densities found in 'salp' years have shifted from the northern region to the southern 3 lines. Highest densities are still in the slope region, but overall frequency of occurrence is usually $>50 \%$. The distribution of larval $P$. antarcticum changed dramatically, with densities in the northern coastal region rapidly dropping to zero. We explored whether these changes in abundance and distribution were linked to changes in seasonal sea ice dynamics and circulation patterns over the past several decades.

\section{Seasonal sea ice dynamics}

Seasonal sea ice dynamics have changed dramatically in the wAP/Bellingshausen Sea, with advance $60.8 \mathrm{~d}$ later and retreat $38.4 \mathrm{~d}$ earlier over the $32 \mathrm{yr}$ record (Stammerjohn et al. 2008, 2012). Ecosystem structure and function are more likely to be impacted by changes in seasonality than absolute sea ice cover (Massom \& Stammerjohn 2010), e.g. earlier water column stratification with alterations in the timing of iceedge or water column phytoplankton blooms (Arrigo et al. 2008, Vernet et al. 2008, Venables et al. 2013) and/or an earlier loss or change in location of habitat for species dependent on ice as a platform or a food resource (Chapman et al. 2011, Lowe et al. 2012). 
Sea ice dynamics likely affect Antarctic krill both through its effects on recruitment and through behavioral responses to sea ice habitat. In a retention system, variation in regional densities will reflect recruitment dynamics, and within-region differences will reflect behavioral or demographic factors. Krill density is sensitive to recruitment success, but 2 to 3 successful years can compensate for several failures (Priddle et al. 1988). For the 3 population cycles here, 2 successful years were followed by 3 to 4 yr of failure. Lowest peak density (2003) followed 4 yr of failure, suggesting that recovery to initial population levels is difficult if $4 \mathrm{yr}$ of failure are followed by only $2 \mathrm{yr}$ of success. The strength of a year class is influenced by a sequence of environmental conditions impacting food availability for spawning and larval survival that can go back 2 yr (Quetin \& Ross 2003, Atkinson et al. 2012). First, reproductive output is correlated with sea ice retreat, likely through its effect on the availability of spring food essential for ovarian development (Hagen et al. 2001, Quetin \& Ross 2001). The critical role of high primary production in spring and summer in successful reproduction and subsequent recruitment the following summer is supported by the correlation between krill abundance and primary production lagged 2 yrs (Year 3 of the population cycle) (Steinberg et al. in press). Larval survival is affected by food availability in summer and fall prior to sea ice advance (Lowe et al. 2012), and by the presence of the sea ice microbial community (SIMCO) as a food source during their first winter (Ross \& Quetin 1991, Quetin et al. 1996, Meyer 2011 and references therein, Flores et al. 2012a,b, Lowe et al. 2012). Successful recruitment is associated with an early ice advance and its effect on SIMCO availability in winter (Quetin et al. 2007) and a minimum duration (Siegel \& Loeb 1995, Quetin \& Ross 2003), supporting the concept that larval survival over winter is the critical parameter most sensitive to climate change (Flores et al. 2012a). However, a successful year class requires multiple seasons with contrasting sea ice requirements; this concept is supported by the correlation of krill recruitment with a 15 mo neutral ENSO index (Fig. 8), and by modeling studies (Wiedenmann et al. 2009).

Within the study region, we suggest there is broad effect of ice edge dynamics on distribution that is not reflected in grid-wide or large-scale indices. Age structure was consistent north to south, i.e. the shift in the location of highest krill densities to the south was not due to spatial differences in the distribution of demographic groups. Larval and juvenile krill are associated with the sea ice habitat in winter (Quetin et al.
1996, Frazer et al. 2002), and higher densities of subadult and adult krill occur at the sea ice edge in spring (Quetin et al. 1992, Brierley et al. 2002, Zhou \& Dorland 2004, Flores et al. 2012b). With their chemosensory and swimming abilities, adult krill are capable of controlling their distribution (Kanda et al. 1982, Price 1989, Hamner \& Hamner 2000). The shift from sea ice to open water habitat may be triggered by changes in habitat-specific food availability. We speculate that krill associate with the retreating ice edge and its food sources until water-column phytoplankton blooms are present, then switch habitats. With earlier sea ice retreat, the location of the ice edge when incident light and mixed layer depth foster spring phytoplankton blooms will be further south, as will the krill when they disassociate from the sea ice. Thus, a behavioral response to the relative abundance of alternate food resources may underlie the location of highest krill densities in summer.

On the larger grid-wide scale, the contrast of changing sea ice dynamics and unchanging density and $\mathrm{R}_{1}$ for krill means that correlations of sea ice advance and duration with recruitment are no longer significant as they were earlier in the time series (Quetin \& Ross 2003, 1993-2002). Timing of retreat remains important to recruitment. However, the shift southward in highest densities suggests that behavioral responses to the changing sea ice and associated environmental factors operate on the smaller scale of $100 \mathrm{~s}$ of $\mathrm{km}$. Seasonal sea ice dynamics may now be optimal for successful recruitment further south, but circulation within the gyres and behavior means krill are found throughout the study region. If the trends in sea ice continue, optimal conditions for production may continue to shift south and out of the study region, and krill will drastically decrease in the northern region in the next decade. However, the lack of krill at high latitudes, in cold continental shelf waters and extreme light regimes, suggests that movement south has limits.

In previous studies, abundance and distribution of $S$. thompsoni have been strongly correlated with seasonal sea ice dynamics (Siegel \& Loeb 1995, Atkinson et al. 2004, Ross et al. 2008, Loeb et al. 2009). However, neither abundance nor the A:S ratio were consistently associated with sea ice dynamics. The movement of the ACC with the salp source population and its warmer water closer to the shelf may mean that the proximity of the ACC to the shelf is now the determining parameter in the study region. In the northern wAP, Loeb et al. (2010) suggested that, with climate change, the former drivers of structure and function of the ecosystem, e.g. sea ice, are no longer as important. 


\section{Circulation patterns}

As the ACC has moved poleward and closer to the shelf break, eddy activity has potentially increased (Marschall 2003, Böning et al. 2008). Eddies form at the shelf break, particularly near the Marguerite Trough, and move warm UCDW onto the mid-shelf (Martinson \& McKee 2012), with specific location(s) dictated by the interaction of the ACC with bathymetry (Dinniman \& Klinck 2004, Dinniman et al. 2011). Specific locations may have changed as the ACC has moved poleward. Near the continent, the APCC, a strongly seasonal coastal current, flows to the southwest (Beardsley et al. 2004, Moffat et al. 2008). The APCC is sensitive to sea ice dynamics, forming in spring and summer after ice melts, and disappearing after winter ice forms. Coastal flow to the northeast is absent during ice-free times, but frequently occurs in winter (Moffat et al. 2008).

Salpa thompsoni. Increased salp densities at slope stations since 2000, higher frequency of occurrence grid-wide, and movement of highest densities south suggested a range extension onto the shelf and poleward. However, the high densities of 'salp' years have decreased in frequency and have disappeared in the northern region. One possible explanation is changes in locations or how salp populations reach the shelf. Initially, in the PAL LTER region, the mean position of the ACC, and associated dense salp populations, may have been further offshore and the incursion of salps onto the shelf due to large meanders in the ACC flooding the shelf. Now, with the ACC closer to the shelf, eddies may routinely introduce salps to the shelf and the frequency of occurrence has increased. Martinson \& McKee (2012) found subsurface eddies, potentially with salp seed populations, primarily moved onto the shelf in the southern regions, as the ACC encounters the Marguerite Trough. A historical change in the main location of the ACC interaction with the shelf could cause the range shift south. In other oceans, such shelf/ current interactions are predictors of salp patches (Deibel \& Paffenhöfer 2009).

With earlier sea ice retreat and intensified eddy activity, the increasing heat content of the shelf, first observed in 1998 (Martinson et al. 2008), will continue. Warmer shelf water should promote salp growth and blooms, and be associated with indicators of bloom progression. Although salp bloom indices (A:S ratio and embryo abundance) showed significant variation in seasonal succession in January, all 'early' stage years were prior to the shift. In two of the later years $(2003,2004)$, a well-developed bloom was present, but densities of solitaries and embryos were lower than in other well-developed bloom years. For these years, the overwintering seed population (solitaries) may have been lower than in 'salp' years. Exploring variable input in seed populations and/or the complexities of the necessary environmental conditions for 'salp' years is beyond the scope of this paper.

Pleuragramma antarcticum. Density of larval $P$. antarcticum in the wAP is generally 10 times less than in the Weddell Sea. Maximum densities in this study were similar to those off the Biscoe Islands in the late 1970s and 1980s (Kellermann 1986, Kellermann \& Schadwinkel 1991). The abrupt decrease in larval $P$. antarcticum densities in the northern coastal region has persisted, as densities at southern coastal stations increased. The loss of larval $P$. antarcticum in the northern region could be due to: (1) loss of a local source population, (2) loss of connectivity to the northern region from a distant source population, or (3) decrease in larval survival only in the north.

Spawning sites for $P$. antarcticum appear restricted to high latitude waters off or near ice shelves, and sea ice plays a role in spawning and nursery grounds (Vacchi et al. 2004, 2012). Kellermann (1986, 1996) suggested the wAP region is on a spawning location periphery, and that spawning grounds for larval $P$. antarcticum in the wAP are in northeastern Bellingshausen Sea continental shelf waters. Antarctic silverfish in the Weddell Sea and in Croker Passage (between Bransfield and Gerlache Straits) are unlikely sources due to the lack of connectivity and/or the age structure of the population (Reisenbichler 1993, La Mesa \& Eastman 2012). The presence of spawning size adults in the southern coastal region, including Marguerite Bay (Donnelly \& Torres 2008, authors' unpubl. 1993-2008 data) supported a spawning population in the southern PAL LTER.

In other locations, 8 to $9 \mathrm{~mm}$ larvae hatch in late November to December (Kellermann 1986, Hubold 1990, La Mesa et al. 2010). In the PAL LTER region, lengths of larval $P$. antarcticum in early January are consistent with these hatching times and observed growth rates $\left(0.15 \mathrm{~mm} \mathrm{~d}^{-1}\right.$, this study; 0.15 to $0.25 \mathrm{~mm}$ $\mathrm{d}^{-1}$, Guglielmo et al. 1997, La Mesa et al. 2010). Several potential pathways may move larvae from the postulated spawning area (Kellermann 1996) northeast to the PAL LTER region. First, drifters released near Marguerite Bay moved offshore into the ACC, occasionally turning inshore at $65^{\circ} \mathrm{S}$ (Zhou et al. 2002, Beardsley et al. 2004), possibly transporting larvae northeast along the shelf edge to the northern slope and shelf stations. However, larval P. antarcti- 
cum were never found at outer stations on any of the lines, negating this possibility.

Second, the coastal flow to the northeast and its sensitivity to changing seasonal sea ice dynamics (Moffat et al. 2008) may play a role. Larval $P$. antarcticum from Marguerite Bay and the coastal Bellingshausen Sea could be transported in the seasonal coastal flow northeast along Adelaide Island. At current speeds of 6 to $10 \mathrm{~cm} \mathrm{~s}^{-1}$, larvae would take $\sim 2$ mo to move $500 \mathrm{~km}$ from Marguerite Bay to the northern PAL LTER region (Beardsley et al. 2004, Moffat et al. 2008). During the 1990s, when the region was ice-covered during November and most of December, this current could have transported larval $P$. antarcticum from spawning grounds either inside or south of Marguerite Bay northeast into the northern PAL LTER region. With earlier ice retreat (Stammerjohn et al. 2008, 2012), the length of time the coastal flow to the northeast exists in late spring will decrease, if it exists at all, and movement of larval $P$. antarcticum to the northern PAL LTER region will cease. Our observations suggest that this possibility may have occurred in the late 1990s.

\section{Ecosystem function and comparison to the northern wAP}

Peak PAL LTER krill densities were similar to maximums in the SW Atlantic, although the long-term mean for the longer SW Atlantic time series was greater (230 ind. $10^{3} \mathrm{~m}^{-3}$, Siegel 2005). Recruitment success in the PAL LTER region and the northern wAP are coherent (Siegel et al. 2003) with similar mean AC1 densities (33 recruits $10^{3} \mathrm{~m}^{-3}$ ) (Siegel et al. 2013). However, in the northern wAP, the recent pattern of $3 \mathrm{yr}$ of successful recruitment before failure (2000-2002, 2005-2007) (Loeb et al. 2010) was not fully reflected in the PAL LTER (2001-2002, 2006-2007). Also, links to the underlying coupled atmospheric-oceanic processes may differ; successful recruitment in the northern wAP is correlated with neutral or La Niña conditions, not neutral ENSO conditions as for the PAL LTER. In the northern WAP, more subtle ENSO-related factors appear to have replaced the role of winter sea ice in krill recruitment (Loeb et al. 2010).

Salps are generally associated with CDW, and higher abundances in the northern wAP (median for 'salp' years $>325$ zooids $10^{3} \mathrm{~m}^{-3}$ ) (Loeb \& Santora 2012) may reflect the proximity of the ACC to the sampling area. Salps are also significantly correlated with ENSO in the northern wAP (Loeb et al. 2009), unlike the PAL LTER region. Density anomalies showed that prior to 2000, 'salp' years in the 2 regions were not coherent, but subsequent anomalies were in the same direction (Fig. 11B). Loeb et al. (2009) and Loeb \& Santora (2012) characterized the shift in conditions from salp- to krill-favorable after the rapid shift from El Niño to La Niña conditions in 1998 as a 'regime shift', and attributed it to the southeasterly movement of the southern ACC front. The rapid shift coincided with changes in multiple parameters in the PAL LTER study region (Martinson et al. 2008, Ross et al. 2008, Smith et al. 2008, Stammerjohn et al. 2008, Vernet et al. 2008), and with the change in the pattern of salp frequency of occurrence and density. Within the PAL LTER region, salp abundance and distribution were initially strongly correlated with seasonal sea ice dynamics; however, with the movement of the ACC closer to the shelf break, the strong correlations have weakened. Salp abundance and distribution in both the northern wAP and in the PAL LTER region likely now both respond to the proximity of the ACC.

Shifts in the location of highest krill densities may also affect ecosystem function through predators tied to land-based breeding grounds. The decrease in Adélie penguins nesting near Palmer Station has been attributed to changes in prey abundance or location, among other factors (Emslie \& Patterson 2007, McClintock et al. 2008, Moline et al. 2008, Chapman et al. 2011). However, only Adélie penguin populations are decreasing; other krill-dependent species (chinstrap and Gentoo penguins) have been increasing (Moline et al. 2008). In contrast, in the northern wAP and Scotia Sea, all 3 species have declined (Trivelpiece et al. 2011). Trivelpiece et al. (2011) suggested that declining penguin populations in the northern wAP and Scotia Sea/South Georgia regions are likely a consequence of increased competition for krill from other predators and declining krill populations due to climate change (Atkinson et al. 2004, 2008). This dichotomy needs additional research.

\section{Summary}

Antarctic krill are a long-lived species with episodic recruitment and the ability as adults to control their distribution. No significant changes in patterns of grid-wide density or recruitment were seen, but the shift south in highest densities suggested that if trends in sea ice continue krill will disappear from the northern region within 2 decades. In contrast, 
salps have a seasonal cycle, and abundance and distribution patterns more closely associated with that year's environmental conditions. Larval $P$. antarcticum are restricted to coastal areas, and distributions are likely controlled by the success of distant spawning populations and seasonal currents that transport the larvae. The postulated environmental change underlying the shift southward of the highest densities differed. Krill shift from feeding on ice-associated food to the open water column once blooms are established; with earlier ice retreat, the change in habitat will occur further south, and so will highest densities in summer. Increased frequency of occurrence and the range extension of $S$. thompsoni is likely due to the poleward movement of the southern boundary of the ACC, with small eddies in the southern region inputting seed populations onto the shelf. Changes in the timing of the coastal flow northeast due to earlier sea ice retreat combined with the fixed hatching time of larval $P$. antarcticum may underlie cessation of larval transport into the northern region. A change in salp frequency of occurrence and the disappearance of larval Antarctic silverfish from the northern coastal region coincided with a sharp increase in the heat content of the shelf (Martinson et al. 2008) and a rapid shift in ENSO conditions. Ecosystem structure and function, as seen in the geographical gradients and ratios of salp:krill abundance, varied with the krill population cycle, emphasizing that knowledge of the phase of episodic recruitment is critical for interpreting relative abundance and trends in shorter-term studies. Ecosystem dynamics are impacted by changes in composition and distribution of the grazers and prey items, with effects ranging from changes in grazing pressure in conjunction with the population cycle to shifts in areas of highest abundance away from land-based nesting seabirds. Large interannual variability in the absolute and relative densities of the 2 major macrozooplankton grazers will lead to highly variable grazing intensity and fecal production and sinking.

Acknowledgements. Constructive comments and questions from anonymous reviewers greatly improved the manuscript. We gratefully acknowledge all the graduate students and volunteers who were critical to data collection. Without the ship-handling skills of the captains, mates, and crews of the MV 'Polar Duke' and ARSV 'Laurence M. Gould', and help of Antarctic Support Associates and Raytheon Polar Services personnel, the samples would never have made it to the deck. Discussions with P. Kremer on salp population dynamics early in the PAL LTER and during manuscript preparation were invaluable. M. White of the British Antarctic Survey and REU student C. Hoffman were critical in the development of the fish larval identification decision tree.
This material is based upon work supported by the National Science Foundation, Office of Polar Programs, under Award Nos. OPP-9011927, OPP-9632763, OPP-0217282, and ANT1010688, The Regents of the University of California, the University of California at Santa Barbara, and the Marine Science Institute, UCSB. This is Palmer LTER contribution No. 490.

\section{LITERATURE CITED}

Aitchison J (1955) On the distribution of a positive random variable having a discrete probability mass at the origin. J Am Stat Assoc 50:901-908

Arrigo KR, van Dijken GL, Bushinsky S (2008) Primary production in the Southern Ocean, 1997-2006. Geophysical Res 113:C08004

Atkinson A, Siegel V, Pakhomov EA, Rothery P (2004) Longterm decline in krill stock and increase in salps within the Southern Ocean. Nature 432:100-103

Atkinson A, Shreeve RS, Hirst AG (2006) Natural growth rates in Antarctic krill (Euphausia superba): II. Predictive models based on food, temperature, body length, sex, and maturity stage. Limnol Oceanogr 51:973-987

Atkinson A, Siegel V, Pakhomov EA, Rothery P and others (2008) Oceanic circumpolar habitats of Antarctic krill. Mar Ecol Prog Ser 362:1-23

Atkinson A, Nicol S, Kawaguchi S, Pakhomov E and others (2012) Fitting Euphausia superba into Southern Ocean food-web models: a review of data sources and their limitations. CCAMLR Sci 19:219-245

- Beardsley R, Limeburner R, Owens WB (2004) Drifter measurements of surface currents near Marguerite Bay on the western Antarctic Peninsula shelf during austral summer and fall, 2001 and 2002. Deep-Sea Res II 51:1947-1964

> Bernard KS, Steinberg DK, Schofield OM (2012) Summertime grazing impact of the dominant macrozooplankton off the Western Antarctic Peninsula. Deep-Sea Res I 62: $111-122$

Böning CW, Dispert A, Visbeck M, Rintoul SR, Schwarzkopf RU (2008) The response of the Antarctic Circumpolar Current to recent climate change. Nat Geosci 1:864-869

Brierley AS, Fernandes PG, Brandon MA, Armstrong F and others (2002) Antarctic krill under sea ice: elevated abundance in a narrow band just south of ice edge. Science 295:1890-1892

Casareto BE, Nemoto T (1986) Salps of the Southern Ocean (Australian Sector) during the 1983-84 summer, with special reference to the species Salpa thompsoni, Foxton 1961. Mem Natl Inst Polar Res Spec Issue 40:221-239

> Chapman EW, Hofmann EE, Patterson DL, Ribic CA, Fraser WR (2011) Marine and terrestrial factors affecting Adélie penguin Pygoscelis adeliae chick growth and recruitment off the western Antarctic Peninsula. Mar Ecol Prog Ser 436:273-289

> Chiba S, Ishimaru T, Hosie GW, Wright SW (1999) Population structure change of Salpa thompsoni from austral mid-summer to autumn. Polar Biol 22:341-349

> Clarke A, Tyler PA (2008) Adult krill feeding at abyssal depths. Curr Biol 18:282-285

> Daniels RA, Lipps JH (1982) Distribution and ecology of fishes of the Antarctic Peninsula. J Biogeogr 9:1-9

> Daponte MC, Capitanio FL, Esnal GB (2001) A mechanism for swarming in the tunicate Salpa thompsoni (Foxton, 1961). Antarct Sci 13:240-245

de la Mare WK (1994) Estimating krill recruitment and its variability. CCAMLR Sci 1:55-69 
Deibel D, Paffenhöfer GA (2009) Predictability of patches of neritic salps and doliolids (Tunicata, Thaliacea). J Plankton Res 31:1571-1579

Dinniman MS, Klinck JM (2004) A model study of circulation and cross shelf exchange on the west Antarctic Peninsula continental shelf. Deep-Sea Res II 51: 2003-2022

> Dinniman MS, Klinck JM, Smith WOJ (2011) A model study of Circumpolar Deep Water on the West Antarctic Peninsula and Ross Sea continental shelves. Deep-Sea Res II 58:1508-1523

> Donnelly J, Torres JJ (2008) Pelagic fishes in the Marguerite Bay region of the West Antarctic Peninsula continental shelf. Deep-Sea Res II 55:523-539

Ducklow HW, Baker K, Martinson DG, Quetin LB and others (2007) Marine pelagic ecosystems: the West Antarctic Peninsula. Philos Trans R Soc Lond B 362:67-94

Edwards M, Richardson AJ (2004) The impact of climate change on the phenology of the plankton community and trophic mismatch. Nature 430:881-884

Emslie SD, Patterson WP (2007) Abrupt recent shift in $\delta^{13} \mathrm{C}$ and $\delta^{15} \mathrm{~N}$ values in Adèlie penguin eggshell in Antarctica. Proc Natl Acad Sci USA 104:11666-11669

Everson I (2000) Role of krill in marine food webs: the Southern Ocean. In: Everson I (ed) Krill: biology, ecology and fisheries, Book 6. Blackwell Science, Oxford, p 194-201

Everson I, Bone DG (1986) Effectiveness of the RMT8 system for sampling krill (Euphausia superba) swarms. Polar Biol 6:83-90

Flores H, Atkinson A, Kawaguchi S, Krafft BA and others (2012a) Impact of climate change on Antarctic krill. Mar Ecol Prog Ser 458:1-19

Flores H, van Franeker JA, Siegel V, Haraldsson M and others (2012b) The association of Antarctic krill Euphausia superba with the under-ice habitat. PLoS ONE 7:e31775

Foxton P (1966) The distribution and life-history of Salpa thompsoni Foxton with observations on a related species, Salpa gerlachei Foxton. Disc Rep 32:1-116

> Frazer TK, Quetin LB, Ross RM (2002) Abundance, sizes and developmental stages of larval krill, Euphausia superba, during winter in ice-covered seas west of the Antarctic Peninsula. J Plankton Res 24:1067-1077

- Garibotti IA, Vernet M, Ferrario ME, Smith RC, Ross RM, Quetin LB (2003) Phytoplankton spatial distribution patterns along the western Antarctic Peninsula (Southern Ocean). Mar Ecol Prog Ser 261:21-39

Gilbert RD (1987) Statistical methods for environmental pollution monitoring. Van Nostrand Reinhold Company, New York, NY

> Gille ST (2002) Warming of the Southern Ocean since the 1950s. Science 295:1275-1277

> Guglielmo L, Granata A, Greco S (1997) Distribution and abundance of postlarval and juvenile Pleuragramma antarcticum (Pisces, Nototheniidae) off Terra Nova Bay (Ross Sea, Antarctica). Polar Biol 19:37-51

> Hagen W, Kattner G, Terbrüggen A, van Vleet ES (2001) Lipid metabolism of Antarctic krill Euphausia superba and its ecological implications. Mar Biol 139:95-104

$>$ Hamner WM, Hamner PP (2000) Behavior of Antarctic krill (Euphausia superba): schooling, foraging, and antipredatory behavior. Can J Fish Aquat Sci 57 (Suppl 3): 192-202

> Hempel G (1987) The krill-dominated pelagic system of the Southern Ocean. Environ Int 13:33-36

Hofmann EE, Husrevoglu YS (2003) A circumpolar modeling study of habitat control of Antarctic krill (Euphausia superba) reproductive success. Deep-Sea Res II 51:
$1323-1331$

Hubold G (1990) Seasonal patterns of ichthyoplantton distribution and abundance in the Southern Weddell Sea. In: Kerry K, Hempel G (eds) Antarctic ecosystems: ecological change and conservation. Springer, Berlin, p 149-158

Kanda K, Takagi K, Seki Y (1982) Movement of the larger swarms of Antarctic krill Euphausia superba populations of Enderby Land during 1976-77 season. J Tokyo Univ Fish 68:25-42

Kawaguchi K, Ishikawa S, Matsuda O (1986) The overwintering strategy of Antarctic krill (Euphausia superba Dana) under the coastal fast ice off the Ongul Islands in Lutzow-Holm Bay, Antarctica. Mem Natl Inst Polar Res Spec Issue 44:67-85

Kellermann A (1986) Geographical distribution and abundance of postlarval and juvenile Pleuragramma antarcticum (Pisces, Notothenioidei) off the Antarctic Peninsula. Polar Biol 6:111-119

Kellermann A (1996) Midwater fish ecology. In: Ross RM, Hofmann EE, Quetin LB (eds) Foundations for ecological research west of the Antarctic Peninsula, Book 70. American Geophysical Union, Washington, DC, p 231-256

Kellermann A, Schadwinkel S (1991) Winter aspects of the ichthyoplankton community in Antarctic Peninsula waters. Polar Biol 11:117-127

King JC, Turner J, Marschall GJ, Connolley WM, LachlanCope TA (2003) Antarctic Peninsula climate variability and its causes as revealed by instrumental records. In: Domack E, Burnett A, Leventer A, Convey P, Kirby M, Bindschadler R (eds) Antarctic Peninsula climate variability: historical and palaeoenvironmental perspectives, Book 79. American Geophysical Union, Washington, DC, p 17-30

> La Mesa M, Eastman JT (2012) Antarctic silverfish: life strategies of a key species in the high-Antarctic ecosystem. Fish Fish 13:241-266

La Mesa M, Eastman JT, Vacchi M (2004) The role of notothenioid fish in the food web of the Ross Sea shelf waters: a review. Polar Biol 27:321-338

> La Mesa M, Catalano B, Russo A, Greco S, Vacchi M, Azzali $M$ (2010) Influence of environmental conditions of spatial distribution and abundance of early life stages of Antarctic silverfish, Pleuragramma antarcticum (Nototheniidae), in the Ross Sea. Antarct Sci 22:243-254

> Lancraft TM, Hopkins TL, Torres JJ, Donnelly J (1991) Oceanic micronektonic macrozooplanktonic community structure and feeding in ice covered Antarctic waters during the winter (AMERIEZ 1988). Polar Biol 11: $157-167$

- Lascara CM, Hofmann EE, Ross RM, Quetin LB (1999) Seasonal variability in the distribution of Antarctic krill, Euphausia superba, west of the Antarctic Peninsula. Deep-Sea Res I 46:951-984

> Loeb V, Santora JA (2012) Population dynamics of Salpa thompsoni near the Antarctic Peninsula: growth rates and interannual variations in reproductive activity (1993-2009). Prog Oceanogr 96:93-107

> Loeb V, Siegel V, Holm-Hansen O, Hewitt R, Fraser W, Trivelpiece W, Trivelpiece S (1997) Effects of sea-ice extent and krill or salp dominance on the Antarctic food web. Nature 387:897-900

> Loeb V, Hofmann EE, Klinck JM, Holm-Hansen O, White WB (2009) ENSO and variability of the Antarctic Peninsula pelagic marine ecosystem. Antarct Sci 21:135-148

$>$ Loeb V, Hofmann EE, Klinck JM, Holm-Hansen O (2010) Hydrographic control of the marine ecosystem in the South Shetland-Elephant Island and Bransfield Strait 
region. Deep-Sea Res II 57:519-542

Lowe AT, Ross RM, Quetin LB, Vernet M, Fritsen CH (2012) Simulating larval Antarctic krill growth and condition factor during fall and winter in response to environmental variability. Mar Ecol Prog Ser 452:27-43

Mackas DL, Batten S, Trudel M (2007) Effects on zooplankton of a warmer ocean: recent evidence from the Northeast Pacific. Prog Oceanogr 75:223-252

- Mackas DL, Greve W, Edwards M, Chiba S and others (2012a) Changing zooplankton seasonality in a changing ocean: comparing time series of zooplankton phenology. Prog Oceanogr 97-100:31-62

Mackas DL, Pepin P, Verheye H (2012b) Interannual variability of marine zooplankton and their environments: withinand between-region comparisons. Prog Oceanogr 97-100: $1-14$

Mackey A, Atkinson A, Hill S, Ward P, Cunningham N, Johnston NM, Murphy EJ (2012) Antarctic macrozooplankton of the southwest Atlantic sector and Bellingshausen Sea: historical distributions; relationships with food; and implications for ocean warming. Deep-Sea Res II 59-60:130-146

Mackintosh NA (1934) Distribution of the macroplankton in the Atlantic sector of the Antarctic. Discov Rep 9:67-160

Marshall GJ (2003) Trends in the Southern annular mode from observations and reanalyses. J Clim 16:4134-4143

> Martinson DG, McKee DC (2012) Transport of warm Upper Circumpolar Deep Water onto the western Antarctic Peninsula continental shelf. Ocean Sci 8:433-442

Martinson DG, Stammerjohn SE, Iannuzzi RA, Smith RC, Vernet M (2008) Western Antarctic Peninsula physical oceanography and spatio-temporal variability. Deep-Sea Res II 55:1964-1987

> Massom RA, Stammerjohn SS (2010) Antarctic sea ice change and variability - physical and ecological implications. Polar Sci 4:149-186

Mauchline J (1980) Measurement of body length of Euphausia superba Dana. BIOMASS Handbook 4:1-9

McClintock J, Ducklow HW, Fraser W (2008) Ecological response to climate change on the Antarctic Peninsula. Am Sci 96:302-310

Meredith MP, King JC (2005) Rapid climate change in the ocean west of the Antarctic Peninsula during the second half of the 20th century. Geophys Res Lett 32:L19604 doi: 19610_11029/12005GL024042

Meyer B (2011) The overwintering of Antarctic krill, Euphausia superba, from an ecophysiological perspective. Polar Biol 35:25-37

Moffat C, Beardsley R, Owens B, van Lipzig N (2008) A first description of the Antarctic Peninsula Coastal Current. Deep-Sea Res II 55:277-293

Moline MA, Karnovsky NJ, Brown Z, Divoky GJ and others (2008) High latitude changes in ice dynamics and their impact on polar marine ecosystems. Ann N Y Acad Sci 1134:267-319

> Nicol S (2000) Understanding krill growth and aging: the contribution of experimental studies. Can J Fish Aquat Sci 57:168-177

$>$ Nicol S (2006) Krill, currents, and sea ice: Euphausia superba and its changing environment. Bioscience 56: 111-120

Nicol S, Pauly T, Bindoff NL, Wright S and others (2000) Ocean circulation off east Antarctica affects ecosystem structure and sea-ice extent. Nature 406:504-507

> Nishikawa J, Tsuda A (2001) Diel vertical migration of the tunicate Salpa thompsoni in the Southern Ocean during summer. Polar Biol 24:299-302
Orsi AH, Whitworth TI, Nowlin WD Jr (1995) On the meridional extent and fronts of the Antarctic Circumpolar current. Deep-Sea Res 42:641-673

Pakhomov EA (2004) Salp/krill interactions in the eastern Atlantic sector of the Southern Ocean. Deep-Sea Res II 51:2645-2660

> Pakhomov EA, Froneman PW, Perissinotto R (2002) Salp/krill interactions in the Southern Ocean: spatial segregation and implications for the carbon flux. DeepSea Res II 49:1881-1907

> Pakhomov EA, Dubischar CD, Hunt BPV, Strass V and others (2011a) Biology and life cycles of pelagic tunicates in the Lazarev Sea, Southern Ocean. Deep-Sea Res II 58: 1677-1689

Pakhomov EA, Hall J, Williams MJM, Hunt BPV, Stevens CJ (2011b) Biology of Salpa thompsoni in waters adjacent to the Ross Sea, Southern Ocean, during austral summer 2008. Polar Biol 34:257-271

Parkinson CL, Cavalieri DJ (2012) Antarctic sea ice variability and trends, 1979-2010. The Cryosphere 6:871-880

Pennington M (1983) Efficient estimators of abundance, for fish and plankton surveys. Biometrics 39:281-286

Perissinotto R, Pakhomov EA (1998) Contribution of salps to carbon flux of marginal ice zone of the Lazarev Sea, Southern Ocean. Mar Biol 131:25-32

Piñones A, Hofmann EE, Dinniman MS, Klinck JM (2011) Lagrangian simulation of transport pathways and residence times along the western Antarctic Peninsula. Deep-Sea Res II 58:1524-1539

Piñones A, Hofmann EE, Daly KL, Dinniman MS, Klinck JM (2013) Modeling the remote and local connectivity of Antarctic krill populations along the western Antarctic Peninsula. Mar Ecol Prog Ser 481:69-92

> Price H (1989) Swimming behavior of krill in response to algal patches: a mesocosm study. Limnol Oceanogr 34: 649-659

Priddle J, Croxall JP, Everson I, Heywood RB, Murphy EJ, Prince PA, Sear CB (1988) Large-scale fluctuations in distribution and abundance of krill-a discussion of possible causes. In: Sahrhage D (ed) Antarctic Ocean and resources variability. Springer-Verlag, Berlin Heidelburg, p 169-182

> Quetin LB, Ross RM (2001) Environmental variability and its impact on the reproductive cycle of Antarctic krill. Am Zool 41:74-89

Quetin LB, Ross RM (2003) Episodic recruitment in Antarctic krill Euphausia superba in the Palmer LTER study region. Mar Ecol Prog Ser 259:185-200

Quetin LB, Ross RM, Prézelin BB, Haberman KL, Hacecky KL, Newberger T (1992) Palmer LTER program: biomass and community composition of euphausiids within the peninsula grid, November 1991 cruise. Antarct J US 27: 244-245

Quetin LB, Ross RM, Frazer TK, Haberman KL (1996) Factors affecting distribution and abundance of zooplankton, with an emphasis on Antarctic krill, Euphausia superba. In: Ross RM, Hofmann EE, Quetin LB (eds) Foundations for ecological research west of the Antarctic Peninsula, Book 70. American Geophysical Union, Washington, DC, p 357-371

> Quetin LB, Ross RM, Fritsen CH, Vernet M (2007) Ecological responses of Antarctic krill to environmental variability: can we predict the future? Antarct Sci 19:253-266

Reisenbichler KR (1993) Growth and chemical composition in two populations of the Antarctic silverfish, Pleuragramma antarcticum (Pisces, Nototheniidae). MSc thesis, University of California, Santa Barbara, CA 
Ross RM, Quetin LB (1991) Ecological physiology of larval euphausiids, Euphausia superba (Euphausiacea). Mem Queensl Mus 31:321-333

Ross RM, Quetin LB, Lascara CM (1996) Distribution of Antarctic krill and dominant zooplankton west of the Antarctic Peninsula. In: Ross RM, Hofmann EE, Quetin LB (eds) Foundations for ecological research west of the Antarctic Peninsula. American Geophysical Union, Washington, DC, Antarctic Research Series 70:199-217

Ross RM, Quetin LB, Haberman KL (1998) Interannual and seasonal variability in short-term grazing impact of Euphausia superba in nearshore and offshore waters west of the Antarctic Peninsula. J Mar Syst 17:261-273

Ross RM, Quetin LB, Martinson DG, Iannuzzi RA, Stammerjohn SS, Smith RC (2008) Palmer LTER: patterns of distribution of five dominant zooplankton species in the epipelagic zone west of the Antarctic Peninsula, 1993-2004. Deep-Sea Res II 55:2086-2105

Schmidt K, Atkinson A, Steigenberger S, Fielding S and others (2011) Seabed foraging by Antarctic krill: implications for stock assessment, bentho-pelagic coupling, and the vertical transfer of iron. Limnol Oceanogr 56:1411-1428

Siegel S (1956) Nonparametric statistics for the behavioral sciences. McGraw-Hill, New York, NY

Siegel V (1988) A concept of seasonal variation of krill (Euphausia superba) distribution and abundance west of the Antarctic Peninsula. In: Sahrhage D (ed) Antarctic Ocean and resources variability. Springer-Verlag, Berlin, p 219-230

Siegel V (2005) Distribution and population dynamics of Euphausia superba: summary of recent findings. Polar Biol 29:1-22

Siegel V, Loeb V (1995) Recruitment of Antarctic krill Euphausia superba and possible causes for its variability. Mar Ecol Prog Ser 123:45-56

Siegel V, Piatkowski U (1990) Variability in the macrozooplankton community off the Antarctic Peninsula. Polar Biol 10:377-386

Siegel V, Loeb V, Gröger J (1998) Krill (Euphausia superba) density, proportional and absolute recruitment and biomass in the Elephant Island region (Antarctic Peninsula) during the period 1977 to 1997. Polar Biol 19:393-398

> Siegel V, Ross RM, Quetin LB (2003) Krill (Euphausia superba) recruitment indices from the western Antarctic Peninsula: are they representative of larger regions? Polar Biol 26:672-679

Siegel V, Reiss CS, Dietrich KS, Haraldsson M, Rohardt G (2013) Distribution and abundance of Antarctic krill (Euphausia superba) along the Antarctic Peninsula. Deep-Sea Res I 77:63-74

Smetacek V, Nicol S (2005) Polar ocean ecosystems in a changing world. Nature 437:362-368

Smith RC, Baker KS, Fraser WR, Hofmann EE and others (1995) The Palmer LTER: a long-term ecological research program at Palmer Station, Antarctica. Oceanography 8: 77-86

Smith DA, Hofmann EE, Klinck JM, Lascara CM (1999) Hydrography and circulation of the West Antarctic Peninsula continental shelf. Deep-Sea Res I 46:925-949

Smith RC, Martinson DG, Stammerjohn SS, Iannuzzi RA, Ireson K (2008) Bellingshausen and western Antarctic Peninsula region: pigment biomass and sea-ice spatial/

Editorial responsibility: Edward Durbin,

Narragansett, Rhode Island, USA temporal distributions and interannual variability. DeepSea Res II 55:1949-1963

Stammerjohn SS, Martinson DG, Smith RC, Yuan X, Rind D (2008) Trends in Antarctic annual sea ice retreat and advance and their relation to ENSO and Southern Annular Mode variability. J Geophys Res 113:C03S90

> Stammerjohn SS, Massom RA, Rind D, Martinson DG (2012) Regions of rapid sea ice change: an inter-hemispheric seasonal comparison. Geophys Res Lett 39:L06501, doi: 10.1029/2012GL050874

Stein M (1988) Variation of geostrophic circulation off the Antarctic Peninsula and in the Southwest Scotia Sea. In: Sahrhage D (ed) Antarctic Ocean and resources variability. Springer-Verlag, Heidelburg, p 81-91

Steinberg DK, Ruck KE, Gleiber MR, Garzio LM and others (in press) Long-term changes in macrozooplankton off the Western Antarctic Peninsula. Deep-Sea Res I

> Tarling GA, Shreeve RS, Hirst AG, Atkinson A, Pond DW, Murphy EJ, Watkins JL (2006) Natural growth rates in Antarctic krill (Euphausia superba): I. Improving methodology and predicting intermolt period. Limnol Oceanogr 51:959-972

Trivelpiece WZ, Hinke JT, Miller AK, Reiss CS, Trivelpiece SG (2011) Variability in krill biomass links harvesting and climate warming to penguin population changes in Antarctica. Proc Natl Acad Sci USA 108:7625-7628

Turner J, Colwell SR, Marschall GJ, Lachlan-Cope TA and others (2005) Antarctic climate change during the last 50 years. Int J Climatol 25:279-294

Vacchi M, La Mesa M, Dalù M, MacDonald J (2004) Early life stages in the life cycle of Antarctic silverfish, Pleuragramma antarcticum in Terra Nova Bay, Ross Sea. Antarct Sci 16:299-305

- Vacchi M, DeVries AL, Evans CW, Bottaro M, Ghigliotti L, Cutroneo L, Pisano E (2012) A nursery area for the Antarctic silverfish Pleuragramma antarcticum at Terra Nova Bay (Ross Sea): first estimate of distribution and abundance of eggs and larvae under the seasonal sea ice. Polar Biol 35:1573-1585

> Venables HJ, Clarke A, Meredith MP (2013) Wintertime controls on summer stratification and productivity at the western Antarctic Peninsula. Limnol Oceanogr 58: 1035-1047

Vernet M, Martinson DG, Iannuzzi RA, Stammerjohn SE and others (2008) Primary production within the sea-ice zone west of the Antarctic Peninsula: I-Sea ice, summer mixed layer, and irradiance. Deep-Sea Res II 55: 2068-2085

> Walther GR, Post E, Convey P, Menzel A and others (2002) Ecological responses to recent climate change. Nature 416:389-395

Waters KJ, Smith RC (1992) Palmer LTER: A sampling grid for the Palmer LTER program. Antarct J US 27:236-239

Wiedenmann J, Cresswell KA, Mangel M (2009) Connecting recruitment of Antarctic krill and sea ice. Limnol Oceanogr 54:799-811

Zhou M, Dorland RD (2004) Aggregation and vertical migration behavior of Euphausia superba. Deep-Sea Res II 51: 2119-2138

Zhou M, Nijler PP, Hu JH (2002) Surface currents in the Bransfield and Gerlache Straits. Deep-Sea Res II 49: 267-280

Submitted: January 22, 2014; Accepted: July 23, 2014

Proofs received from author(s): November 5, 2014 